Portland State University

PDXScholar

6-18-1992

\title{
Attitude Functions and Political Behavior: the Issue of Gay Civil Rights
}

Josephine Young

Portland State University

Follow this and additional works at: https://pdxscholar.library.pdx.edu/open_access_etds

Part of the Psychology Commons

Let us know how access to this document benefits you.

\section{Recommended Citation}

Young, Josephine, "Attitude Functions and Political Behavior: the Issue of Gay Civil Rights" (1992). Dissertations and Theses. Paper 4531.

https://doi.org/10.15760/etd.6415

This Thesis is brought to you for free and open access. It has been accepted for inclusion in Dissertations and Theses by an authorized administrator of PDXScholar. Please contact us if we can make this document more accessible: pdxscholar@pdx.edu. 
AN ABSTRACT OF THE THESIS OF Josephine Young for the Master of Science in Psychology presented June 18, 1992.

Title: Attitude Functions and Political Behavior: The Issue of Gay Civil Rights.

APPROVED BY THE MEMBERS OF THE THESIS COMMITTEE:
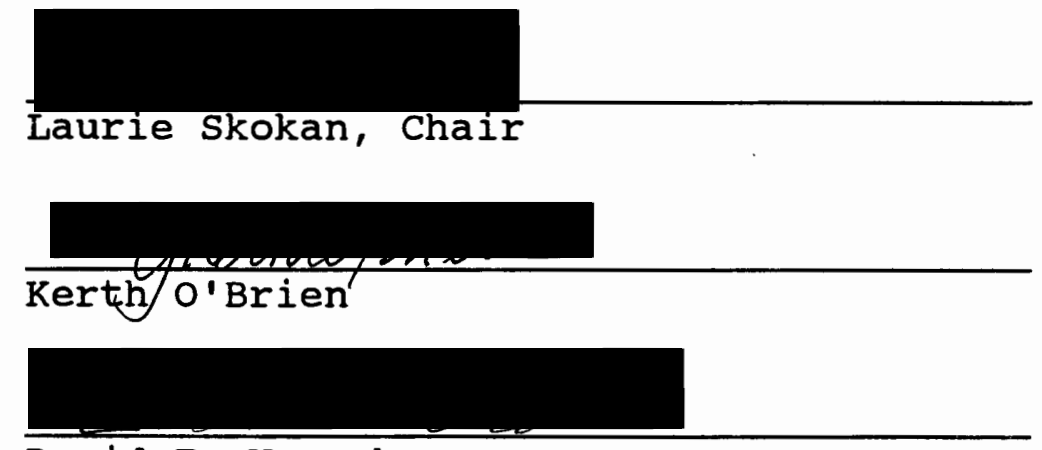

David F. Wrench

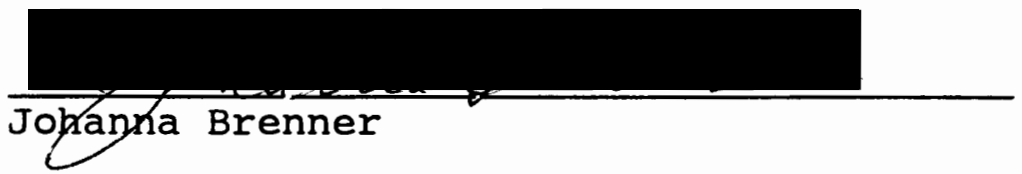

This study explored the relationship between voters' political behavior regarding the issue of gay rights and the underlying psychological needs served by their attitudes on this issue. A telephone survey of 100 randouly selected local voters was conducted, during which Herek's (1987) Attitude Functions Inventory (AFI) was administered. Three of the four attitude function subscales (ExperientialSchematic, Social-Expressive and Ego-Defensive) were confirmed using a LISREL confirmatory factor analysis. The 
Value-Expressive subscale was not confirmed and showed poor reliability. Pro- and anti-gay rights behavior was measured using a Political Behavior Index (PBI) developed for this study. Regression analyses and MANOVAs were employed to test six hypotheses, all of which received some support. Pro-gay rights behavior was associated with ExperientialSchematic attitudes and a Value-Expressive item regarding civil liberties. Anti-gay rights behavior was associated with Ego-Defensive attitudes and a Value-Expressive item regarding moral beliefs. Men scored higher on the EgoDefensive function than did women. Those who knew more gay people were more likely to exhibit Experiential-Schematic attitudes and were less likely to hold Ego-Defensive attitudes. These findings imply that efforts to change anti-gay rights behavior need to address the underlying motivations of Ego-Defense and Value-Expression regarding the construct of moral beliefs. An additional implication is a potential for increasing support for the legal rights of gay people by increasing association with people one knows to be gay. 


\title{
ATTITUDE FUNCTIONS AND POLITICAL BEHAVIOR: \\ THE ISSUE OF GAY CIVIL RIGHTS
}

\author{
by \\ JOSEPHINE YOUNG
}
A thesis submitted in partial fulfillment of the requirements for the degree of
MASTER OF SCIENCE
in
PSYCHOLOGY

\author{
Portland State University \\ 1992
}


TO THE OFFICE OF GRADUATE STUDIES:

The members of the Committee approve the thesis of Josephine Young presented June 18, 1992.

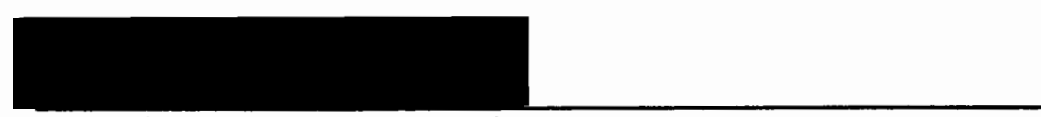

Laurie skokan, Chair

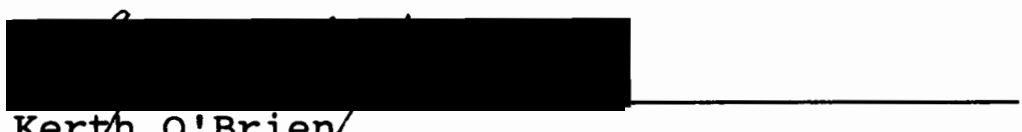

Kerth O'Brien

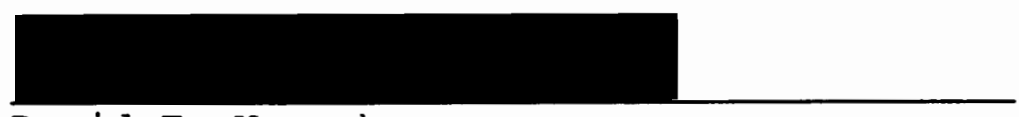

David F. Wrench

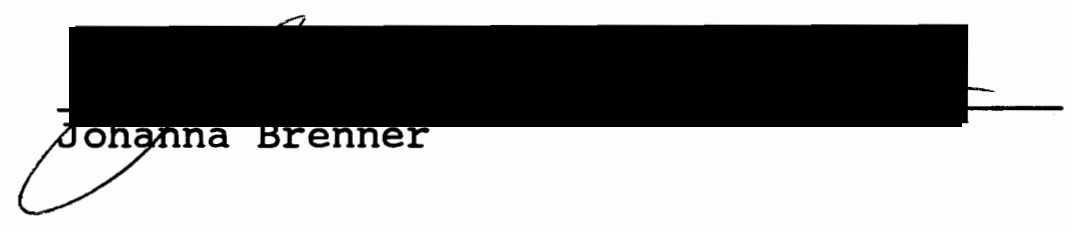

APPROVED :

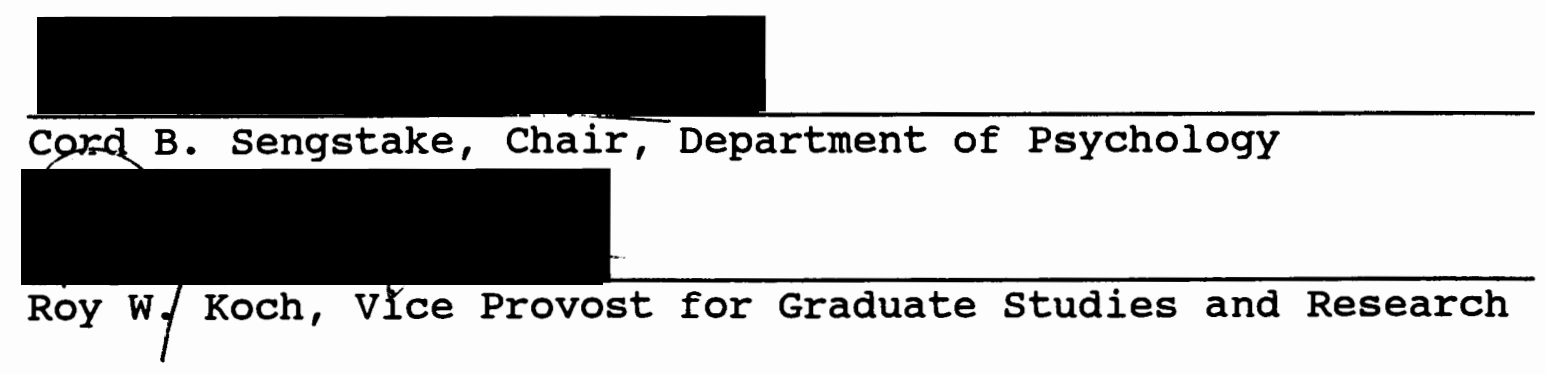




\section{DEDICATION}

This work is dedicated to all who struggle against bigotry, intolerance and oppression. 


\section{ACKNOWLEDGEMENTS}

I offer heartfelt thanks to the faculty of the Psychology Department of Portland State University and to my life partner for the support and encouragement they have provided me. Special appreciation goes to the members of my thesis committee, and above all, to chair Laurie skokan. 
TABLE OF CONTENTS

PAGE

ACKNOWLEDGEMENTS . . . . . . . . . . . . . iii LIST OF TABLES . . . . . . . . . . . . . . . . v INTRODUCTION . . . . . . . . . . . . . . . 1 The Socio-Political context . . . . . . . . 4 Review of Research Findings and Public opinion Surveys . . . . . . . . . . . . . . . 13

Relevant Theories . . . . . . . . . . 16 Hypotheses . . . . . . . . . . . . . . 24 METHOD . . . . . . . . . . . . . . . 29 Sample . . . . . . . . . . . . . . . 29 Measures ................. 30 Procedure .................. . 32 RESULTS . . . . . . . . . . . . . . . . . . 33 DISCUSSION . . . . . . . . . . . . . . . 4 47 REFERENCES . . . . . . . . . . . . . . . . 59 APPENDICES

A HEREK'S (1987) ATTITUDE FUNCTIONS INVENTORY • • 62

B QUESTIONNAIRE: ATTITUDE FUNCTIONS AND POLITICAL BEHAVIOR: THE ISSUE OF GAY CIVIL RIGHTS • 64 


\section{LIST OF TABLES}

TABLE

PAGE

I Attitude Functions Inventory (AFI) . . . . . 36

II Measures of Overall Goodness of Fit . . . . . 37

III Standardized Solution Factor Loadings . . . . 37

IV Phi Matrix . . . . . . . . . . . . 37

V Political Behavior Index (PBI) . . . . . . 38

VI Correlations Between Attitude Functions . . . 39

VII Mean Scores on Attitude Functions by Number of Gay People Known . . . . . . . . . . . 40

VIII Multiple Regression of Attitude Functions of

Political Behavior . . . . . . . . . 42

IX Correlations of selected Variables with PBI

Scores . . . . . . . . . . . 46 


\section{INTRODUCTION}

An attitude is a theoretical construct, the definition, conceptualization and structure of which is still being debated by psychologists. Ajzen has defined an attitude as an evaluative "disposition to respond favorably or unfavorably to an object, person, institution, or event, or to any other discriminable aspect of the individual's world" (1989, p. 241). A disposition may be expressed either verbally or nonverbally in thoughts (cognition), feelings (affect), or actions (conation). Herek, on the other hand, has presented a functional definition of attitudes as "strategies for satisfying psychological needs" (1986a, p. 99). Regardless of how one chooses to define them, attitudes are inarguably correlated with behavior that affects real people.

Attitudes play a key role in intergroup relations. While favorable attitudes toward an outgroup may be associated with pleasant relations, negative attitudes toward targeted outgroups has often resulted in stigmatization, discrimination, oppression and violence directed at members of those groups. One such group is homosexuals. (Homosexual women generally prefer to be referred to as lesbian in order to assert a visible identity distinctive from homosexual men who identify as gay. 
Because the media has popularized the term "gay rights" to refer to legal rights for homosexual women and men, this writer has used the terms "homosexuals" and "gay people" to include both lesbians and gay men. It should be noted that the legal interests of bisexual people, who may have same-sex partners, are also incorporated in the issue referred to as "gay rights".)

The convergence of two social movements has created a socio-political milieu in which opposing attitudes toward homosexual men and women have become increasingly important. On the one hand, the Gay Liberation movement, which began on June 27, 1969 following a police raid of the stonewall Inn in Manhattan's Greenwich Village, has gathered momentum over the last 20 years. In the face of continuing legally sanctioned discrimination and the government's failure to effectively address the HIV epidemic, many gay people have been prompted to "come out of the closet" and to seek redress. On the other hand, conservative religious fundamentalists have become increasingly politically mobilized during the past decade in response to widespread social and economic changes that have taken place during the latter half of this century. Known as the Moral Majority, the New Right, or the Christian Right, they have gained considerable influence within the Republican party and the federal judiciary during the Reagan and Bush administrations (Diamond, 1989). Promoting and capitalizing upon intolerant 
attitudes toward homosexuality, which in their view is sinful and immoral, has been a major tactic used by the religious right in galvanizing political support. Oregon is presently one of two states (Colorado is the other) where the religious right-wing is testing strategies to pass anti-gay legislation. At the same time, proponents of gay rights have been actively seeking the passage of legislation that would ban discrimination on the basis of sexual orientation.

Opposing views of homosexuality are at the heart of the conflict. One view holds that homosexuality is immoral behavior that can and should be avoided. The other view holds that a homosexual or bisexual orientation is as intrinsic to some people as a heterosexual orientation is to others, and that a heterosexual orientation is not morally superior. Depending on which viewpoint prevails, the outcome promises to have a profound impact on attitudes toward and treatment of gay and bisexual people in the years ahead.

Using Herek's functional approach to the study of attitudes, the present study sought to explore the relationship between the underlying psychological functions of voters' attitudes and their political behavior regarding the issue of legal rights for homosexuals. It is hoped that insights gained will facilitate development of interventions leading to improved relations between a heterosexual 
majority and homosexual and bisexual minorities. First, an in-depth description of the socio-political context is presented, followed by a review of pertinent studies and public opinion surveys, a discussion of some relevant theories, and the hypotheses of this study.

\section{THE SOCIO-POIITICAL CONTEXT}

While many groups of people who have historically been targets of discrimination (i.e. women, racial and ethnic minorities, religious groups, the handicapped) have received, at least on paper, civil rights protections at virtually all levels of government, at least one group of citizens has failed to receive such protections. This group is comprised of individuals identified as homosexual because their romantic and/or sexual partners are of their same gender.

In all 50 states same-sex partners are denied the right to marry and to enjoy the concomitant legal, spousal, and economic benefits (joint property rights, inheritance, tax benefits, medical insurance, bereavement leave, parental leave, child custody, social security benefits, etc.). Indeed, in many states, homosexual acts are proscribed by law (Herek, 1989). As of April 1992, only six states (Massachusetts, Wisconsin, Hawaii, Connecticut, New Jersey and Vermont) had passed laws attempting to protect gay 
people from discrimination in employment, housing and public accommodations.

During the last decade, over 100 local governments throughout the nation have passed anti-discrimination laws. However, opponents of such laws, who frequently have been identified as right-wing conservatives and religious fundamentalists, are actively attempting to overturn them. Gay rights ordinances in st. Paul, Minnesota and Concord, California were referendum targets in 1991. (St. Paul's held, while Concord's was overturned.) In Oregon's 1991 legislative session, an anti-discrimination bill (Senate Bill 708) passed the Democrat-controlled senate, but died in committee in the Republican-controlled House. California's Republican governor vetoed similar legislation in 1991 after being pressured to do so by conservatives.

The stances of the two political parties on this issue are noteworthy. The Democratic party has generally supported legislation favorable to discriminated-against minority groups. The Republican party, on the other hand, has become increasingly dominated, from the precinct level to the national level, by the right-wing (Diamond, 1989). Protection from discrimination is also lacking at the national level. The U. S. military routinely discharges gay men and lesbians when their sexual orientation is disclosed. U. S. immigration laws have historically barred homosexuals 
from entering this country (Stoddard, Boggan, Haft, Lister \& Rupp, 1983).

Help from the courts is not likely to be forthcoming.

In the 1986 supreme Court case of Bowers vs. Hardwick, Chief Justice Burger stated:

Decisions of individuals relating to homosexual conduct have been subject to state intervention throughout the history of Western Civilization. Condemnation of those practices is firmly rooted in Judeo-Christian moral and ethical standards . . - To hold that the act of homosexual sodomy is somehow protected as a fundamental right would be to cast aside millennia of moral teaching (Melton, 1989, p. 933).

Psychologists are mandated by the American

Psychological Association's Ethical Principles of

Psychologists (1981) to:

- . strive for the preservation and protection of fundamental human rights . . . Guided by the primary obligation to aid the public in developing informed judgments, opinions, and choices . . . they are committed to increasing knowledge of human behavior . . and to the utilization of such knowledge for the promotion of human welfare (Preamble, Principle $4 . \mathrm{g}$ ).

When:

- . laws, regulations, or practices are in conflict with Association standards and guidelines, psychologists. . . work toward changing existing regulations that are not beneficial to the public interest (Principle 3.d).

In accordance with these principles, the APA has filed amicus briefs in Bowers vs. Hardwick and other court cases which involved discrimination against homosexuals. As pointed out by Melton (1989): 
Psychology can contribute to courts' understanding of the depth of antigay prejudice that persists in the United States, the lack of relationship between homosexuality and ability to respond to job requirements and other social demands, the near-impossibility of changing homosexual orientation, and the deleterious effects of continuing discrimination on mental health and social relations (p. 934).

At the personal level, being viewed by the institutions of society as immoral and/or criminal because of homosexual behavior and therefore undeserving of legal recourse against discrimination has resulted in suffering for countless numbers of people. In addition to the distress caused by the risk of being stigmatized and vulnerable to discrimination, people who are perceived as being gay are frequent targets of physical assault. It is clear that the current legal and social status of homosexuals facilitates rationalization of oppressive and violent actions by those who experience feelings of fear and hatred toward gay people (Herek, 1989).

Responding to the problem of prejudice-motivated crimes, Congress passed the Hate crimes statistics Act in April 1990 which directs the Department of Justice to collect statistics on crimes motivated by bias that is based on race, religion, ethnicity or sexual orientation. The oregon legislature passed a similar bill in 1989 directing law enforcement agencies to report prejudice-motivated crimes to the Executive Department. (It is noteworthy that 
in each case the attempt to include sexual orientation met with strong opposition.)

Local reports of hate crimes are increasing significantly (Hill, 1991; Potter, 1991), but probably represent only a fraction of actual incidents. Many gay people are afraid of reporting prejudice-motivated abuse for fear of losing their jobs or of being further stigmatized (Herek, 1989; D. Redwing, personal communication, sept 23, 1991; Sorensen, 1991).

In addition to improved record-keeping resulting from passage of the hate crimes statistics acts, there are other factors which may help account for the rise in locally reported hate crimes against gay people. Portland, Oregon has a both large and visible gay and lesbian community that has been actively seeking to make civil rights gains since the early 1970's. The city has been a target area for recruitment by white supremacist groups which preach hatred of gays, Jews and people of color. Furthermore, a right wing political group comprised largely of religious fundamentalists, the oregon Citizens Alliance (OCA), has been active at the state and local levels since 1987. The OCA identifies its members as "conservative Christians" who, among other things, have declared a holy war against "the homosexual agenda." In their view, "This concept of persons being given special rights and privileges because of their deviant sexual orientation challenges, if not subverts, the 
entire fabric of America's foundation" ("The homosexuals' agenda," 1991, p. 1). Following a vocal leadership, OCA supporters have proven to be active letter-writers and signature-gatherers.

In 1988, the OCA introduced a state-wide ballot measure, Ballot Measure 8, that was successful in revoking then-governor Neil Goldschmidt's executive order (87-20) that prohibited discrimination on the basis of sexual orientation within the state's executive branch. The OCA used a "No special Rights" theme for their ballot campaign. (Gay rights supporters ran their unsuccessful "No on 8" campaign with an appeal to fairness.) "No special rights" for homosexuals was also included as one of the campaign platform statements when the OCA ran an independent candidate for governor in 1990.

The OCA actively opposed passage of SB708 by the state legislature in the spring of 1991. This bill would have prohibited discrimination on the basis of sexual orientation. OCA supporters also testified against an ordinance passed October 3, 1991 by Portland's city council which bans discrimination on the basis of sexual orientation and source of income. (Chief Justice Burger's statement in Bowers vs. Hardwick was not lost to this group. At least two opponents of the city ordinance quoted it at the public hearings on september 25 and 26, 1991). The OCA formed a "No Special Rights" committee to have sexual orientation 
removed from the ordinance. They were unsuccessful in gathering enough valid signatures that would have placed their ballot measure in the May 1992 election. However, they did succeed in placing anti-gay initiatives on the ballots in the oregon cities of springfield and corvallis. While their anti-gay initiative was defeated in corvallis, it passed in Springfield with about 55\% of the vote. Since then, a city councilor who supported the measure has "requested a list of books ordered by the city library in the last six months", having "heard that the children's library included a book about a child with homosexual parents" (Monje, 1992, p. G8). He is quoted as stating "What we want to make sure of is that the head librarian is complying with the law and community values."

At this writing, the OCA is collecting signatures for a state-wide initiative that would declare homosexuality a perversion and that would essentially prohibit further attempts to gain civil rights protections for or public acceptance of homosexuals. The initiative declares:

This state shall not recognize any categorical provision such as "sexual orientation", "sexual preference," and similar phrases that includes homosexuality, pedophilia, sadism or masochism . . . State, regional, local governments and their properties and monies shall not be used to promote, encourage, or facilitate homosexuality . . . agencies . . . including specifically the state Department of Higher Education and the public schools, shall assist in setting a standard for oregon's youth that recognizes homosexuality, pedophilia, sadism and masochism as abnormal, wrong, unnatural, and 
perverse and that these behaviors are to be discouraged and avoided.

In an effort to gain support for this initiative, the OCA is distributing throughout the state 10,000 copies of an inflammatory video entitled "Gay Pride?" (A similar strategy was successfully used by gay-rights opponents in concord, CA.)

Local gay and lesbian groups and their allies formed a "No on Hate" campaign to fight these measures through grassroots educational efforts and possibly through a media campaign. A state-wide coalition of gay rights supporters, The Campaign for a Hate Free oregon, also has recently formed. In an apparent attempt to confuse voters, the OCA recently filed an initiative titled "No on Hate" seeking to change the wording of the state's intimidation law (ORS 166.155) from "sexual orientation" to "abnormal and unnatural sexual behavior".

Several large Portland businesses, (Fred Meyer, Inc., Cub Foods, and Lloyd center) have attempted to bar signature-gathering efforts by the OCA, as well as by other petitioners, from their premises because of complaints from customers (Rubenstein, 1992). Subsequently, a supporter of the OCA (though he claims not to be a member) filed a $\$ 12$ million federal lawsuit against Fred Meyer, Inc., the state's gay rights organizations and leaders, the City of Portland, the city's Police Chief and his daughter, and an ACLU attorney, alleging that they have acted to "intimidate 
and prevent a despised class of people with certain beliefs from lawfully exercising their constitutional right to influence the course of government" (Cohn, 1992, p. 1).

The major local newspaper, The oregonian, has generally been sympathetic to the cause of gay civil rights, though it has also given much coverage to the $O C A$ and featured its leader, Lon Mabon, after a boycott by the OCA. The governor, the mayor, and the chief of police have been publicly supportive of anti-discrimination measures, as have many other public figures and church leaders. The OCA called for the resignation of the police chief following his appearance in the June 1991 Gay Pride march with his lesbian daughter. Extensive and on-going media coverage, both locally and nationally, of the OCA's anti-gay activities has made it likely that the issue of civil rights for homosexuals is a salient one for many local voters.

In addition to the proposed OCA-sponsored initiatives that may appear before voters in 1992, some local voters are also being presented with the historical opportunity of voting for two openly lesbian officials, both of whom were appointed to office in 1991. One of these candidates is running for the state House of Representatives and the other is running for judge. These campaigns may further enhance issue salience to voters regarding acceptable societal roles for homosexuals. Therefore, the current socio-political context has made this study particularly timely. 
REVIEW OF RESEARCH FINDINGS AND PUBLIC OPINION SURVEYS

A review of empirical research by Herek (1984) and Kite (1984) indicated that across numerous studies the following findings have consistently been associated with more negative views toward homosexuals: 1) lacking personal contact with lesbians or gay men; 2) associating with peers who have negative attitudes toward homosexuals; 3) growing up in areas where negative attitudes were normative, such as rural areas, the South and Midwest; 4) being older and/or less-educated; 5) having conservative religious beliefs or reporting frequent church attendance; 6) expressing restrictive attitudes regarding sex roles; 7) exhibiting an authoritarian personality; and 8) being male. In addition, when the homosexual target is of the same sex as the respondent, attitudes are usually more negative than toward homosexuals of the opposite-sex. Other studies have found that those who ascribe homosexuality to an innate cause hold less negative views than those who believe that it is a learned or chosen behavior (Aguero, Bloch, \& Byrne, 1984; Whitley, 1990).

National survey data, reviewed by Schneider and Lewis (1984), corroborated these findings. Education, personal contact with open homosexuals, and the belief that sexual orientation is an inborn characteristic were found to be strongly associated with greater tolerance. In addition to the well-educated, blacks, liberals, Catholics, and those 
from the eastern U. S. were more gay-positive. The Gallup organization obtained similar results (Gallup Report No. 258, 1987). Schneider and Lewis (1984) also reported that those with low incomes, the poorly educated, Protestants, Southerners, conservatives, the strongly religious, and those over 65 were more gay-negative. Men and married people were more opposed to gay rights than were women and the unmarried. Schneider and Lewis concluded that religious intolerance and perceived threats to privileges related to gender and marriage pose major obstacles to acceptance. other national survey results provide further insight into how the heterosexual majority views homosexuals and their legal rights. When asked by the National Opinion Research Center (NORC) about sexual relations between two adults of the same sex in 1973, 1980 and in 1987 , about $80 \%$ of those surveyed responded that homosexual relations are always or almost always wrong (Public Opinion, 1987). Beginning in 1977 Gallup started asking "Do you think homosexual relations between consenting adults should or should not be legal?" Up until 1986 the public was about evenly split. A faltering of support in 1986, dropping from $44 \%$ to $33 \%$ favoring legalization of gay relations, was attributed to the HIV epidemic (Schneider, 1987). That this figure remained at $33 \%$ the following year was interpreted by Gallup to mean that the negative reaction was leveling off (Gallup Report No. 258, 1987). A Gallup survey in late 1985 
showed that of those responding, $38 \%$ indicated that the AIDS epidemic had changed their opinion of homosexuals for the worse (Public Opinion, Dec/Jan 1986). Nationally, 8\% indicated that they planned to avoid homosexual people because of the risk of AIDS (Gallup Report No. 273, 1988). In another late 1985 survey by the Los Angeles Times, 30\% agreed with the statement that AIDS is a punishment God has given homosexuals for the way they live (Public Opinion, Dec/Jan 1986). Gallup received a 43\% agreement to a similar question (The Gallup Report, Jan/Feb 1988).

Schneider \& Lewis (1984) indicated that while many heterosexuals view homosexuality as "wrong" or unnatural, and do not endorse its acceptance as an alternative lifestyle, a majority has indicated some support of legal rights for gay people. This support may be conditional, however. While most people favored a law outlawing job discrimination against various minority groups, a Harris poll indicated that $48 \%$ "felt that homosexuals should be barred from certain kinds of jobs" (Schneider \& Lewis, 1984, p. 18). A 1985 NORC survey showed that $40 \%$ felt that a homosexual should be fired or not allowed to teach at a college or university (Public Opinion, July/Aug 1987) and a 1987 Gallup poll showed that 65\% thought that homosexuals should not be hired as elementary school teachers (Public Opinion, July/Aug 1987). A survey by Roper indicated that $54 \%$ of the respondents strongly objected or preferred not to 
work around homosexuals, while $72 \%$ responded the same way regarding people who have AIDS (Public Opinion, July/Aug 1987). However, in a 1988 Gallup survey, only 25\% said that they would refuse to work alongside someone who has AIDS (Gallup Report, Jan/ Feb 1988). This survey reported an attitude shift toward support for the rights of people with AIDS .

Regarding sex education, a 1985 Gallup poll showed 55\% favoring it in grades 4 through 8 , and $80 \%$ favoring it in a high school curriculum. However, only $28 \%$ thought that homosexuality should be included in elementary school classes and 48\% favored inclusion in high school curricula (Public Opinion, sept/Oct 1986). Support for sex education in general appears to be increasing in response to the HIV epidemic (Schneider, 1987).

\section{RELEVANT THEORIES}

citing the fact that people show less political tolerance toward those whom they perceive as threatening, Green and Waxman (1987) found that when a context of threat existed, people also expressed less tolerance for the civil liberties of groups that weren't directly related to the source of threat. However, this effect was much more pronounced among the less educated. Bobo and Licari (1989) attributed the positive correlation between educational level and political tolerance to improved reasoning skill 
(cognitive sophistication). In studies of people in three nations, Sullivan and Marcus reported "one major source of intolerance . . . was a dogmatic, insecure personality" (1988, p. 30). They pointed out, however, that other factors such as education, social norms, perceived threat, the socio-political context and the historical context can affect levels of political tolerance as well.

Kirk \& Madsen (1989) described the development of feelings of fear and hatred of homosexuals as a two-step process of behavioral conditioning. First, through Direct Emotional Modeling children perceive and automatically experience the emotions of their caretakers. Then, by Associative Conditioning a stimulus and an emotion become linked. For example, if a parent expresses disgust (whether verbally or non-verbally) at the mention of the word "queer" or at the sight of a "queer-looking" person, the child forms an associative link between the category "queers" and feelings of disgust. Such an association may be repeatedly reinforced by peers, certain religious groups, televangelists, some public figures, and the mass media. When surrounded by others who have been similarly conditioned, people are likely to be rewarded by pleasant feelings of increased ingroup bonding and self-righteousness upon expressing such attitudes. Reward will also occur as they relieve the unpleasant feelings of fear and loathing by either avoiding or attacking the object of contempt. 
The majority of acts of violence against homosexuals are committed by young males. Herek (1986a) asserts that this hostility has its roots in the social construction of masculinity, which by definition excludes that which is perceived as being feminine. Because gay people stereotypically blur gender roles, this may arouse strong feelings of anxiety among those who are insecure regarding their own sexuality. This anxiety may be relieved by externalizing the conflict by means of projection in the form of hostility. Men have been found to exhibit more defensive attitudes toward gay people than have women (Herek, 1986b).

Kirk and Madsen's behavioral conditioning explanation appears to fit with Fiske's theory of schema-triggered affect (Fiske \& Taylor, 1991) and Wilson's theory of affective expectancy (cited in Fiske \& Taylor, 1991). For example, when a person's schema for lesbians is activated, the feelings that are attached to that schema will be experienced along with the cognitive images that are evoked regarding the category "lesbians". or, in accordance with Wilson's theory, a person might anticipate how they will feel when they encounter a lesbian. If such an encounter meets their expectation, their affective response will be faster. If the encounter is discrepant with what was expected, the affective response may be disrupted. The finding that people who have actually known a gay person 
generally hold more positive attitudes toward gays as a group would seem to indicate that, at least sometimes, positive experiences are generalized, changing negative schema content and attitudes.

The finding that experience with gay people is more often associated with positive attitudes also supports Allport's Contact Hypothesis (1954), which predicts that contact between ingroup and outgroup members under favorable conditions (1.e. equal status, cooperative interdependence, intimate contact and egalitarian norms) should result in improved intergroup relations. Achieving favorable conditions is often difficult, however, since prejudice and discriminatory laws often preclude conditions of equal status and egalitarian norms for gay people. Moreover, those who feel most threatened by homosexuals are likely to avoid social contact with them.

Ajzen and Fishbein's (1980) Theory of Reasoned Action "remains the most popular single approach for predicting behavior from attitudes" (Tessar and Shaffer, 1990, p. 512). According to this model, the most reliable predictor of behavior is an expressed intention to perform that behavior. Behavioral intention is derived from attitude toward the behavior and the subjective norm (that is, perceptions about what other people think and motivation to comply). Attitude is derived from beliefs and evaluations regarding outcomes. 
The Ajzen-Fishbein model assumes that deliberate, systematic cognitive processing is used in weighing costs and benefits provided by the attitude object. However, ottati (1990) indicated that voters use both normative inferential processes (i.e. those that are deliberate and systematic) and heuristic inferential processes (mental short-cuts based on rules of thumb or global evaluations) depending on the complexity of the task at hand. Whether systematic or heuristic processing is used also depends upon motivation, such as desire for accuracy, ego-defense, or impression-management (Fiske \& Taylor, 1991).

The symbolic perspective of Sears and his colleagues (1980, 1988), in contrast to the Theory of Reasoned Action, highlights different underlying processes. According to Sears, global values and underlying ideologies are better predictors of behavior than are behavioral intentions. Symbolic attitudes combine affect (such as antiblack or antigay affect) with abstract values (such as the belief that no group should receive special treatment, or that sexual behavior is only moral within the confines of heterosexual marriage). These symbolic attitudes may then lead to discriminatory behavior against certain groups. Herek's functional approach to attitudes (1984, 1986a, 1987) incorporates both the utilitarian perspective of the Ajzen-Fishbein model and the symbolic perspective of Sears. Drawing upon earlier works by Smith and by Katz in the 
1950's and 1960's, Herek (1987) identified four functions of attitudes held toward lesbians and gay men: Experiential-Schematic, Defensive, Social-Expressive and Value-Expressive, described below. Experiential-schematic attitudes are instrumentally based on the utility of an attitude object itself, while the other three functions are based on what an attitude object symbolizes and how it relates to self-identity. The amount of affect associated with a given attitude may be influenced by the function that attitude serves. The source of an attitude function depends upon the person, the attitude object and the situation. Herek has noted that "the same attitude can serve different functions for different people, and different functions can be the basis for one individual's attitudes in different domains" (1986a, p. 111) or in different situations, depending upon what gets primed. Thus the functional approach describes the underlying psychological motivations for holding or expressing attitudes.

Experiential-Schematic attitudes serve the utilitarian function of knowledge or object appraisal. Whether based upon one's own experience or upon the experiences of others, these attitudes reflect the processes of categorization, evaluation, and schema formation. They contain evaluations of attitude objects on the basis of relative costs and benefits, thus serving as guides to behavior. For example, 
a voter may decide to support a candidate that promises no new taxes rather than one who advocates more taxes.

Defensive attitudes protect the ego, allowing individuals to relieve intrapsychic stress stemming from insecurities or internal conflicts (for example, regarding sexual identity). This is accomplished by projecting the source of anxiety onto the attitude object. Some people who suffer from feelings of inadequacy, insecurity or low self-worth may seek to feel better about themselves by rationalizing their superiority to members of certain other groups.

Social-Expressive attitudes allow people to meet needs for social approval by publicly expressing attitudes that are congruent with those held by the majority of one's referent group. Not surprisingly, Herek found these attitudes to be more frequently displayed by high self-monitors, who are more sensitive to conforming to social norms. For example, a person might rail against homosexuals when at church, but maintain a pleasant relationship with a gay relative at home.

Value-Expressive attitudes allow people to increase their self-esteem by expressing their internal values. Civil libertarians, the devoutly religious, and low self-monitors (i.e. those who are more sensitive to internal rather than to external cues) are more likely to exhibit these attitudes. For example, a heterosexual might support 
legal rights for homosexuals because of held values of equality and fairness.

To determine which functions are being served, Herek (1987) developed a 10-item Attitude Functions Inventory (AFI) using gay men and lesbians as attitude objects. The AFI has been successfully applied to other attitude objects as well. Anderson \& Kristiansen (1990) found that attitudes toward gay rights and abortion primarily served

Value-Expressive and Ego-Defensive functions, while a principle components factor analysis replicated the presence of four factors as reported by Herek.

The Experiential/Schematic function incorporates both knowledge and evaluation. Heterosexuals who have had more experience with gay people would be expected to have acquired a broader knowledge of gays and their current legal and social status. The Experiential-Schematic function also addresses utilitarian concern regarding self-interest. Since people are more likely to act when self-interest is involved (Fiske \& Taylor, 1991), one might expect those who have the most to gain or lose to be actively involved in this issue. Gay people certainly have much to gain or lose. (It should be noted, however, that self-interest concerns may also actually dissuade some gay people from becoming involved out of fear of potential negative social and economic consequences following their public identification with a stigmatized and legally unprotected group.) 
Additionally, those who are using the emotionally-charged issue as a means of galvanizing political and financial support obviously have much to gain.

Individuals who feel very ego-threatened by homosexuals may be actively involved in the issue (Defensive function). Those who hold strong civil libertarian values and/or religious beliefs are also likely to be active with respect to this issue (Value-Expressive function). For those with a high need for approval from their referent social groups, their involvement may reflect the stance taken by those groups (Social-Expressive function).

\section{HYPOTHESES}

By interviewing a randomly selected sample of local voters, the present study used Herek's AFI to assess the underlying psychological functions of attitudes toward the issue of gay civil rights. The study examined the correlations between these attitude functions and political behavior regarding the issue. The following hypotheses were tested:

1. Those who report knowing more than one gay person are more likely to hold Experiential-Schematic attitudes. Experiential-Schematic attitudes are, by definition, based upon either past or anticipated experiences with one or more representatives of an attitude object, and they may include utility-based evaluations of the attitude object 
(Herek, 1986a). Experience with more members of a category or group can result in more accurate and more complex schema formation, as inaccurate stereotypes are disconfirmed and schema subtyping occurs (Fiske \& Taylor, 1991). Therefore those who have had experiences with more gay people would be expected to hold more accurate, and less stereotyped, schemas of gays.

2. Pro-gay rights behavior is more prevalent among those holding predominantly Experiential-Schematic attitudes.

As a result of their review of public opinion surveys regarding the issue of gay rights, Schneider and Lewis (1984) concluded "Personal contact with people who are openly homosexual consistently produces greater tolerance for homosexuality" (p. 17). Those who have had personal experience with gay people are likely to view gay men and lesbians more positively. Because experience usually results in increased knowledge, they are more likely to be aware of the problems faced by gay people due to lack of legal protections. For those who anticipate continuing or future contact with gay people, the benefits of acting to secure legal protections for gay people are likely to be more apparent.

3. Those who answer "strongly agree" to a Value-Expressive statement, "My opinions about legal rights for homosexuals mainly are based on my concern that we 
safeguard the civil liberties of all people in our society" are more likely than others to report pro-gay rights behavior.

Following administration of the AFI, Anderson and Kristiansen (1990) reported "Subjects' attitudes toward homosexual rights and abortion mainly fulfilled the value-expressive and ego-defensive functions" (p. 420). Those who strongly self-identify as "civil libertarian", or who view protection of civil liberties as essential to their global ideology, are likely to express these civil

libertarian values through behavior that is consistent with such values. That is, people who strongly value civil liberties for all are likely to be motivated to action when they perceive those civil liberties to be threatened. Recent media coverage of the OCA's anti-gay rights initiatives makes it likely that civil libertarians are aware of this issue.

4. Those who answer "strongly agree" to a Value-Expressive statement, "My opinions about legal rights for homosexuals mainly are based on my moral beliefs about how things should be," and who also give a weaker response to the previous Value-Expressive statement regarding civil liberties for all, are more likely to report anti-gay rights behavior.

The OCA's anti-homosexual appeals for support have largely been directed to religious fundamentalists (i.e. 
those who interpret religious teachings literally) and religious conservatives. Equating homosexuality with immorality, their rhetoric has focused on rigidly held beliefs regarding moral behavior. To recognize legally and to protect homosexuals from discrimination is, in their view, to sanction immoral and perverse behavior. Those whose self-concept derives from a fundamentalist religious ideology are likely to express their values in a manner that is consistent with their religious beliefs.

5. Those holding predominantly Ego-Defensive attitudes are expected to report anti-gay rights behavior.

As noted above, Anderson and Kristiansen (1990) found that attitudes regarding legal rights for homosexuals served an ego-defensive function for some of their respondents. Since defensive responses, including increased anxiety and stress, are most likely to be triggered when people who are insecure about their own sexuality come into contact with people who exhibit gender ambiguity or non-conformity, people holding such defensive attitudes are likely to seek to relieve intrapsychic stress either through avoiding or attacking people who they perceive as being gay (Herek, 1986a, 1986b; Kirk \& Madsen, 1989). Because they are more likely to feel personally threatened by the prospect of having to work, dine or live in proximity to homosexuals, those who hold Defensive attitudes are likely to avoid 
potential contact by actively opposing legislation that outlaws discrimination against gays.

6. Those holding Ego-Defensive attitudes are more likely to be male.

This hypothesis anticipates the replication of a previous finding reported by Herek (1986b) in which:

- . attitudes toward gay people served an entirely defensive function for $20 \%$ of the men and $5 \%$ of the women. This evaluation was based on content analysis of essays written by respondents to describe their attitudes toward lesbians and gay men ( $p .565-566$ ).

Masculinity is a social construct that by definition has historically excluded that which is defined as feminine. Moreover, that which is perceived as being masculine has historically been valued over that which is perceived as being feminine. Herek concluded that:

This analysis points toward a hypothesis that heterosexual men have more negative reactions to gay people than do women, on the average, because such hostility is inherent in the cultural construction of heterosexual male role and identity; this is less true for heterosexual female role and identity (p. 566-567). 
METHOD

\section{SAMPLE}

Responses were obtained from 100 voters of both sexes residing in the portland metropolitan area who reported that they were currently registered to vote in this state. The sample was selected as follows.

A listing was randomly selected from the residential section of the current Portland metro area telephone directory. Subsequent listings were selected by fixed intervals from that starting point. (The interval of selection was determined by dividing the total number of residential listings by the desired sample size.) The last digit of each selected telephone number was then increased by 1 to provide the numbers that were actually dialed. The reason for using this procedure was to reduce sampling error by allowing for inclusion of unlisted numbers (Lake \& Harper, 1987). US West declined to reveal what percentage of residential numbers are unlisted and indicated that they do not know what percentage of local households are without a telephone. Nationwide, over $90 \%$ of households reportedly have at least one telephone, especially those in urban areas. Therefore this study assumed that most voters are likely to have a telephone which may or may not be listed. 
Once a number was reached, respondents were selected by using the following filter questions (following a brief introduction):

"Are there any members of your household who are registered to vote in Oregon?"

"Of those registered voters, may I speak with the one who has most recently had a birthday?"

The rationale for asking "the most recent birthday" question was to reduce sampling error. Rather than simply interviewing the first person who answered the phone, it was reasoned that this method should provide for a more representative sample of voters (Lake \& Harper, 1987).

\section{MEASURES}

Attitude functions were classified and scored using Herek's (1987) 10-item Attitude Functions Inventory (AFI). (See Appendix A.) Each of the 10 statements were rated on a 7-point Likert scale ranging from "strongly disagree" to "strongly agree." (Herek used a 9-point scale in written applications of the AFI. However, it was decided that a 9-point scale might be too difficult for telephone respondents.) Individual subscale scores were totaled for each of the four attitude functions.

Four versions of the AFI were created by randomly selecting different orderings of the 10 items. Each subject 
was randomly assigned to receive one of the four differently ordered versions.

A measure of political behavior (Political Behavior Index, PBI) was developed for this study. The PBI was obtained by adding scores on the following 16 potential behaviors: 1) wrote a letter to the editor about the issue; 2) attended a public hearing on the issue; 3) lobbied lawmakers on the issue; 4) gathered signatures for an initiative regarding gay rights; 5) signed issue-related petitions or ballot measure initiatives; 6) donated to groups actively involved in the issue; 7) participated in marches, rallies or public demonstrations related to gay civil rights; 8) spoke publicly on the issue; 9) solicited the involvement of others regarding the issue; 10) took a stance in informal discussions on the issue; 11) displayed bumper stickers, buttons or yard signs regarding the issue; 12) supported or opposed a political candidate because of his or her stance on the issue; 13 ) boycotted or supported any business because of the issue; 14) intended vote to overturn or to keep in place Portland's anti-discrimination ordinance; 15 ) intended vote regarding the OCA's proposed statewide anti-gay rights initiative; 16 ) previous vote on the OCA's 1988 Ballot Measure. Each reported pro-gay rights behavior was scored +1 , each anti-gay rights behavior was scored -1 , and no behavior was scored 0 . 
Demographic variables included sex, age, educational level, marital status, religion, partisan affiliation, and identity as liberal, moderate or conservative. (Income, race/ethnicity and sexual orientation were not asked because of their sensitivity and the length of the survey.)

Approval of the study was obtained from the Human Subjects Research Review Committee prior to pre-testing the questionnaire. Pre-testing indicated the questionnaire to be acceptable regarding both respondent comprehension and potential bias in question wording.

PROCEDURE

Data was collected by telephone interview. Interviews took from 13 to 45 minutes, and lasted about 16 minutes on average. When the respondent indicated that it was not a convenient time an attempt was made to schedule an appointment for a call-back. If there was no answer, up to three call-backs were attempted at various days and times over the following week. Refusals, no-answers, ineligible and in-operable numbers were coded as such. A response rate of about $60 \%$ was anticipated based on response rates obtained for similar random telephone surveys.

Respondents were guaranteed anonymity. They were informed that they could refuse to answer any question and that they could stop the interview at any time. 


\section{RESULTS}

In order to obtain 100 respondents for this study, 432 randomly selected telephone numbers were called during the period of time between March 4 and April 8, 1992. Of those, 50 potential respondents refused to participate in the survey and 74 households reported that they no registered oregon voters. The remainder were non-residential, disconnected or non-working numbers, or no-answers. No-answers were coded as such after four attempts at various times and on different days of the week. Five of the 100 respondents terminated before the survey was completed. Unanswered questions were recorded as missing data.

The response rate of $67 \%$ was well within expectations. Actual response rate was probably somewhat lower than $67 \%$ because some of those who claimed to be non-registered may have been disguised refusals.

of those who responded, 66 were women and 33 were men. (The sex of one respondent was not recorded.) since the sex of those who refused to be interviewed was not recorded, it is not known whether there was a difference in response rate between men and women.

The sample appeared to be evenly distributed with regard to age and political party affiliation. However, only $41 \%$ considered themselves to be close to their party. 
Political stance was distributed with $26 \%$ identifying themselves as conservative, $41 \%$ as moderate, and $20 \%$ as liberal. The median educational level was "some college". Thirty-one percent of the respondents had not attended religious services during the past year, while $40 \%$ reported having attended more than 12 times.

In response to the question "About how many lesbians and gay men would you say that you have ever known personally?", $11 \%$ said "none", $3 \%$ said "one", $36 \%$ indicated "two to five", $43 \%$ indicated "more than five" and $2 \%$ said they were uncertain.

of the 82 respondents who reported that they had known at least one person who was gay or lesbian, 78 (95\%) indicated that their interaction(s) had been mostly pleasant. Eighteen (22\%) reported having a homosexual relative, 55 (67\%) had at least one homosexual friend, and $62(70 \%)$ knew a homosexual co-worker.

sixty-seven percent of the respondents indicated that the issue of legal rights for homosexuals was of moderate or great concern to them as voters. A favorable stance toward gay rights was indicated by $52 \%$, while $33 \%$ indicated they were opposed.

SPSSX and LISREL were used to analyze the data and to evaluate substantive hypotheses. One-tailed tests of significance are reported for hypothesized results. 
Four Attitude Functions Inventory (AFI) subscale scores were computed for each respondent by summing their 7-point Likert-scale responses (recoded to range from $1=$ "strongly disagree" to 7="strongly agree") on each of the subscales. Coefficient alpha was computed for each of the four subscales to examine reliability. As can be seen in Table I, all but the Value-Expressive subscale demonstrated high inter-item reliability.

To examine whether the ordering of the AFI items had any impact on responses, a multivariate analysis of variance (MANOVA) was conducted. The MANOVA, in which the AFI subscales were examined as a function of questionnaire version, revealed no significant order effects.

A LISREL confirmatory factor analysis of Herek's four factor AFI (allowing the factors to correlate) showed an overall goodness of fit index of 0.91 and an adjusted goodness of fit index of 0.85 . However, the Value-Expressive item regarding "moral beliefs" did not load well (-.135). An uninterpretable number $(-1.32)$ also appeared in the phi matrix for the correlation between the Value-Expressive and Ego-Defensive factors. Therefore, a second confirmatory factor analysis was performed eliminating the two Value-Expressive items. The results of this confirmatory analysis are shown in Tables II, III and IV. The Experiential-Schematic, Social-Expressive and Ego-Defensive factors were successfully confirmed. 
TABLE I

ATTITUDE FUNCTIONS INVENTORY (AFI)

\begin{tabular}{|c|c|c|c|c|c|c|}
\hline Attitude Function subscale & Items & $\begin{array}{c}\text { Possible } \\
\text { Range }\end{array}$ & $\begin{array}{l}\text { Actual } \\
\text { Range }\end{array}$ & Mean & std. Dev. & coeff. a \\
\hline Experiential-Schematic & 4 & $4-28$ & $5-28$ & 12.4 & 6.6 & .71 \\
\hline Social-Expressive & 2 & $2-14$ & $2-14$ & 7.2 & 3.9 & .66 \\
\hline Ego-Defensive & 2 & $2-14$ & $2-14$ & 6.0 & 4.1 & .72 \\
\hline Value-Expressive & 2 & $2-14$ & $2-13$ & 11.6 & 2.5 & -.14 \\
\hline
\end{tabular}


TABLE II

MEASURES OF OVERALL GOODNESS OF FIT

\begin{tabular}{lr}
\hline Goodness of Fit Index & 0.92 \\
Adjusted Goodness of Fit Index & 0.86 \\
Root Mean Square Residual & 0.10 \\
Chi Square & 33.25 (20df) $\mathfrak{p}=.03$ \\
\hline
\end{tabular}

TABLE III

STANDARDIZED SOLUTION FACTOR LOADINGS

\begin{tabular}{cccc}
\hline AFI Item & Experiential-Schm & Social-Exp. & Ego-Defense \\
\cline { 2 - 3 } 1 & 0.77 & & \\
2 & 0.66 & & \\
3 & 0.35 & & \\
4 & 0.91 & 0.89 & \\
5 & & 0.56 & \\
6 & & & 0.72 \\
7 & & & 0.86 \\
8 & & & \\
\hline
\end{tabular}

The phi matrix (Table IV), shows the correlations among the three factors (attitude functions).

TABLE IV

PHI MATRIX

\begin{tabular}{lccc}
\hline & Experiential & & Social-Expressive Ego-Defense \\
Experiential & 1.00 & & \\
Social-Expressive & 0.43 & 1.00 & \\
Ego-Defensive & -0.24 & 0.15 & 1.00 \\
\hline
\end{tabular}

Scores on the Political Behavior Index (PBI) ranged from -8 (anti-gay) to +11 (pro-gay) after discarding one score of +15 as an outlier. A negative score indicates 
anti-gay behavior, a positive score indicates pro-gay behavior and a score of zero indicates neither predominantly anti-gay nor predominantly pro-gay behavior. To measure reliability, KR-20 (since items were dichotomous) was computed for the 16-item PBI and was found to be quite acceptable. (See Table V.)

TABLE V

POLITICAL BEHAVIOR INDEX (PBI)

\begin{tabular}{|c|c|c|c|c|}
\hline Behavior scores & Range & Mean & std.Dev. & $\alpha(\mathrm{KR}-20)$ \\
\hline Anti-gay $(\mathrm{N}=18)$ & -1 to -8 & -3.2 & 2.3 & \\
\hline Pro-Gay $(\mathrm{N}=64)$ & 1 to 11 & 3.9 & 1.9 & \\
\hline PBI overall $(\mathrm{N}=91)$ & -8 to 11 & 2.1 & 3.45 & 0.80 \\
\hline
\end{tabular}

To test hypotheses 1 and 6 (1. Those who report knowing more than one gay person are more likely to hold Experiential-Schematic attitudes. 6. Those holding Ego-Defensive attitudes are more likely to be male.) a MANOVA was performed in which attitude functions were examined as a function of number of gay people known and the respondent's sex. Due to the low reliability coefficient of the Value-Expressive subscale and failure to confirm the subscale in the factor analysis, the two items comprising this function (which assessed civil liberties and moral beliefs) were examined separately.

Although the multivariate $\underline{F}$ for attitude functions by sex was not significant, an examination of univariate $\underline{F}^{\prime} s$ 
seemed justified because of the variable correlations between the attitude functions. (See Table VI.) Univariate

\section{TABLE VI}

CORRELATIONS BETWEEN ATTITUDE FUNCTIONS

\begin{tabular}{|c|c|c|c|c|c|}
\hline & EXP & EGO & $\underline{\text { SOC }}$ & Moral & Rights \\
\hline $\operatorname{Exp}$ & 1.0 & & & & \\
\hline Ego & -.10 & 1.0 & & & \\
\hline Soc & $.30+$ & .13 & 1.0 & & \\
\hline Moral & .11 & $.19 *$ & $-.19 *$ & 1.0 & \\
\hline Rights & $.22 * *$ & $-.57 * * *$ & .10 & -.04 & 1.0 \\
\hline
\end{tabular}

results showed that scores on the Ego-Defensive function varied as a function of $\operatorname{sex}(\underline{F}(1,85)=3.50, \underline{p}<.05)$. Men showed a tendency to be more Ego-Defensive than did women, with a mean score of 6.7 for men versus a mean score of 5.2 for women $(r=-.18, \underline{p}<.05)$.

The MANOVA also indicated that the attitude functions varied as a function of number of gay people known $(\underline{E}(10,164)=3.03, \underline{p}<.001)$. For number of gay acquaintances known, univariate $\underline{F}^{\prime} s$ were non-significant for the Social-Expressive function and the Value-Expressive "moral beliefs" item. The univariate F's also indicated that the attitude functions impacted by number of gays known included the Experiential-Schematic and Ego-Defensive functions, as well as the civil rights item. (See Table VII.) Post-hoc scheffe tests revealed that there were significant differences in the attitude function score of 
TABLE VII

MEAN SCORES ON ATTITUDE FUNCTIONS BY NUMBER OF GAY PEOPLE KNOWN

\begin{tabular}{|c|c|c|c|}
\hline \# of gays known & $\begin{array}{l}\text { Exp- } \\
\text { Schm }\end{array}$ & $\begin{array}{l}\text { Ego- } \\
\text { Defense }\end{array}$ & $\begin{array}{c}\text { Value } \\
\text { Civil Rights }\end{array}$ \\
\hline none & 8.7 & 7.4 & 5.1 \\
\hline 1 to 5 & 11.6 & 7.5 & 5.7 \\
\hline more than 5 & 4.2 & 4.2 & 6.7 \\
\hline univariate $\underline{E}(2,85)$ & $3.24 *$ & $9.04 * *$ & $9.04 * *$ \\
\hline
\end{tabular}

$* \mathrm{p}<.02 \quad * * \mathrm{p}<.001$

those who knew more than 5 gay people as compared to those who knew no gay person for the Experiential-Schematic and Ego-Defensive functions. Not surprisingly, those who knew more than five gay people were more likely to agree with the Experiential-schematic items and were less likely to agree with the Ego-Defensive items than those who had known no gay people. With respect to the civil rights item, the scheffe test indicated that there were significant differences between the means of those who knew more than five gay people and 1-5 gay people, and between those who knew more than five gay people and no gay person. Respondents who reported knowing more than five gay people were more likely to agree with the "civil liberties for all" statement than were those knowing either 1-5 gay people or no gay people. standard multiple regression analyses, in which attitude function scores were regressed on PBI scores, were used to test Hypotheses 2 thru 5 (2. Pro-gay rights behavior is more prevalent among those holding predominantly 
Experiential-Schematic attitudes. 3. Those who answer "strongly agree" to a Value-Expressive statement, "MY opinions about legal rights for homosexuals mainly are based on my concern that we safeguard the civil liberties of all people in our society" are more likely than others to report pro-gay rights behavior. 4. Those who answer "strongly agree" to a Value-Expressive statement, "My opinions about legal rights for homosexuals mainly are based on my moral beliefs about how things should be," and who also give a weaker response to the previous Value-Expressive statement regarding civil liberties for all, are more likely to report anti-gay rights behavior. 5. Those holding predominantly Ego-Defensive attitudes are expected to report anti-gay rights behavior.) (See Table VIII.) A standardized scatterplot of residuals permitted a favorable evaluation of assumptions regarding normality, linearity and homoscedasticity. Using a criterion of $\underline{p}<.001$, Mahalanobis distances were checked for the presence of multivariate outliers. No outliers were noted.

As predicted, Ego-Defensive attitudes (Hypothesis 5) and the Value-Expressive item regarding moral beliefs (Hypothesis 4) were significantly associated with anti-gay rights behavior, with Beta weights of -.50 and -.17 , respectively. That is, both those who scored high on the Ego-Defensive functions and those who scored high on the 
TABLE VIII

MULTIPLE REGRESSION OF ATTITUDE FUNCTIONS

OF POLITICAL BFHAVIOR

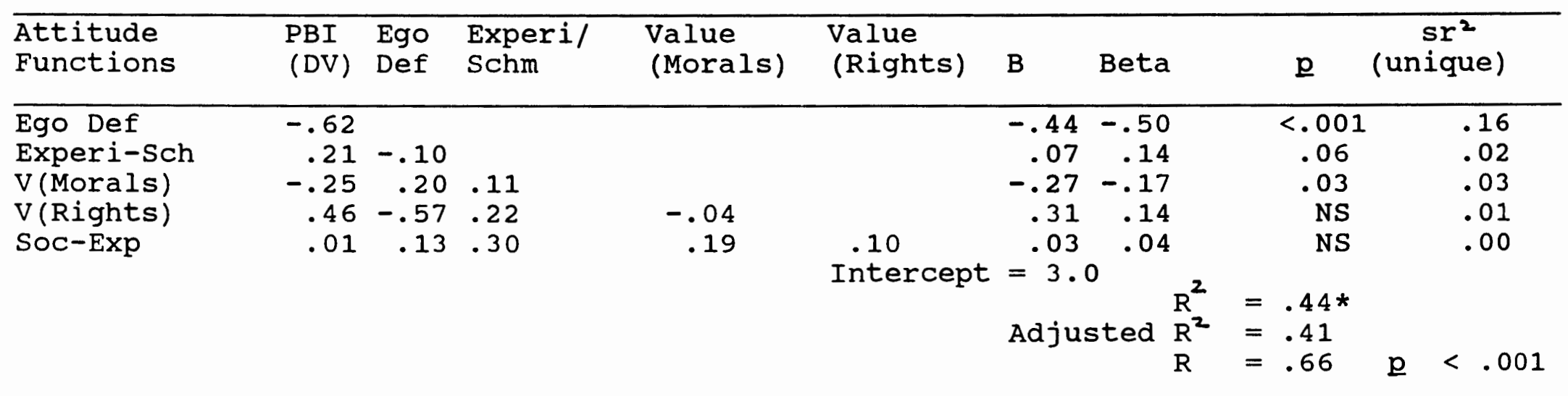

*Unique variability $=.22 ;$ shared variability $=.22$ 
Value-Expressive item regarding moral beliefs reported more anti-gay behavior.

The prediction that Experiential-Schematic attitudes would be associated with pro-gay rights behavior (Hypothesis 2) was supported by a significant correlation between Experiential-Schematic scores and PBI scores $(r=.208, \underline{p}=$ .02). While it did not quite meet the criterion for significance in the regression equation, a definite trend in the predicted direction was observed $(\beta=.14, \underline{\underline{p}}=.06)$.

Respondent agreement with the Value-Expressive item regarding "safeguarding civil liberties for all" showed a significant correlation with pro-gay political behavior as predicted by Hypothesis $3(r=.458, \underline{p}<.001)$. However, this item failed to appear as a significant variable in the regression equation because of a large amount of shared variance with Ego-Defense, with which it was negatively correlated $(r=-.565)$. When entered first in a stepwise regression, the civil rights item was able to account for 21\% of variance in PBI scores. Ego-Defense accounted for $38 \%$ when entered alone. Together the two items accounted for $40 \%$ of the total variance, with the value-Expressive civil rights item failing to reach significance due to its shared variance with Ego-Defense.

Based on the results of AFI scores in this survey, a derived regression equation for prediction of political 
behavior from attitude functions is:

PBI $=3.05-.50$ Ego Defense -.17 Moral Beliefs.

When the demographic variables of sex, age, education, religious attendance, conservative/moderate/liberal, marital status and party affiliation were entered as a block in a hierarchical regression, they accounted for $47 \%$ of variance in PBI scores. These demographic variables together with the four AFI subscale scores produced an $R^{2}$ of $0.66 \quad 0.57$ Adjusted). Of the demographic variables entered, education and marital status were significant in the final equation. Another hierarchical regression was performed by first entering these two demographic variables followed by the two significant attitude functions. Together these four variables (education, marital status, Ego Defense and Moral Beliefs) accounted for $50 \%$ of the variance in PBI scores. Education and marital status accounted for $20 \%$ of this variance. Thus a derived equation for prediction of political behavior scores, using both demographic data and attitude function scores, is:

$\mathrm{PBI}=.99+.27$ Education +.20 Marital Status - .49 Ego Defense - .19 Moral Beliefs.

Follow-up analyses were conducted to further examine results obtained in the multiple regression. A MANOVA with the attitude functions as the dependent variables and marital status as the independent variable was conducted. While the multivariate $\mathbf{E}$ was non-significant, univariate 
results indicated a significant difference in Experiential-schematic scores on the basis of marital status $(\underline{F}(3,75)=3.0, \underline{p}<.05)$. A Scheffe test revealed that single people scored significantly higher on Experiential-Schematic items than did respondents who are married $(\overline{\mathrm{X}}=18.2$ vs $\overline{\mathrm{X}}=10.4)$. There was also a significant correlation between marital status and the Experiential-schematic function $(r=.36, \underline{p}<.001)$.

Similarly, a MANOVA of attitude functions by education was performed, followed by scheffe tests to determine differences between groups. While the multivariate $\mathbf{F}$ was non-significant, univariate results showed that respondents who had gone to graduate school scored significantly lower on Ego-Defense than did those having an educational level of high school or below $(\underline{F}(3,86)=3.07, \underline{p}=.03)$. Mean scores for the two groups were 3.2 for those having done graduate work versus 7.3 for those with no more than a high school level of education. The correlation between education and the Ego-Defense function was negative and significant ( $r=$ $-.27, \underline{p}=.005)$. A higher level of education was also associated with a higher score on the Value-Expressive item regarding civil liberties $(r=.25, \mathrm{p}<.01)$. Though the univariate $\mathrm{F}$ failed to meet the criterion for significance, a supporting trend was indicated $(\underline{F}(3,86)=2.5, \underline{p}=.06)$.

The correlation between respondents' self-reported stance on the issue of gay rights and their reported 
political behavior was high and positive $(r=.72, \underline{p}<$ .001), indicating that most people knew where they stood and acted consistently. There was a moderate positive correlation between correspondents' reported stance on the issue as compared to their perceptions regarding the stance of the majority of people closest to them $(r=.32, \underline{p}=$ $.002)$. Correlations between political behavior scores and selected variables of interest are shown in Table IX.

TABLE IX

CORRELATIONS OF SELECTED VARIABLES

WITH PBI SCORES

\begin{tabular}{llc}
\hline Variable & $\underline{\underline{r}}$ & $\underline{\mathrm{p}}$ \\
Sex & .05 & $\mathrm{NS}$ \\
Marital status & .22 & $<.02$ \\
$\begin{array}{l}\text { Education } \\
\text { \# of gays known }\end{array}$ & .38 & $<.001$ \\
$\begin{array}{l}\text { Frequency of interaction } \\
\text { with gays }\end{array}$ & .35 & $<.001$ \\
$\begin{array}{l}\text { Respondent's stance } \\
\text { (self-reported) }\end{array}$ & .41 & $<.001$ \\
$\begin{array}{l}\text { Friends' stance } \\
\text { on gay rights }\end{array}$ & .72 & $<.001$ \\
\hline
\end{tabular}




\section{DISCUSSION}

In an effort to operationalize the functional approach to the study of attitudes, Herek (1987) developed his Attitude Functions Inventory (AFI) to measure the underlying psychological needs being met by attitudes held toward an attitude object. The instrument was initially developed using gay men and lesbians as the attitude objects, and then applied to other stigmatized groups. Using principle components factor analysis, Herek identified four underlying attitude functions. Acting on the suggestion that the AFI might be used to measure attitudes toward objects in other domains as well, Anderson and Kristiansen (1990) used Herek's AFI to measure functions of attitudes held toward gay rights, abortion, cars and air conditioners. Like Herek, they also identified four attitude functions regarding the issues of gay rights and abortion by using principle components factor analysis, and found that attitudes toward these issues primarily met Ego-Defensive and Value-Expressive needs. Both studies administered the AFI in written form to undergraduate college students. Extending application of the AFI to a more heterogenous population sample and using oral administration via telephone interviews, the present study sought to confirm the presence of the four previously identified attitude 
functions regarding the issue of gay rights by performing a confirmatory factor analysis. Additionally, the present study sought to examine relationships between attitude functions and political behavior regarding civil rights for lesbians and gay men.

Since all but the Value-Expressive function were confirmed, the two Value-Expressive items, civil liberties and moral beliefs, were treated separately. Anderson and Kristiansen's finding that attitudes toward the issue of legal rights for homosexuals were mainly associated with meeting Ego-Defensive and Value-Expressive needs was supported. There was some level of support for each of the six hypotheses postulated in this study. Findings are discussed below.

Respondents who knew more gay people scored higher on the Experiential-Schematic attitude function items. This was expected because AFI items for this function pertain to one's experience with the attitude object. Presumably, those who have had more experience with an object are more likely to have formed evaluations that are knowledge-based. Those who reported having known more than five lesbians and gay men were also found to be more likely to agree with the Value-Expressive statement "MY opinions regarding legal rights for homosexuals mainly are based on my concern that we safeguard the civil liberties of all people in our society." Not surprisingly, those who scored higher on this 
item were also found to exhibit pro-gay rights behavior. According to previously cited research findings, those who know more gay people are likely to view gays more positively. They are also likely to have greater knowledge of existing inequities suffered by gay people and are likely to be more aware of the social costs of continued discrimination. Therefore, those who know more gay people would be expected to be supportive of their seeking civil rights. This reasoning also explains the predicted finding that experience-based attitudes were positively correlated with pro-gay rights political behavior.

However, it should be noted that this study does not attempt to establish a causal direction. It may be that those who are less prejudiced are more likely to engage in social interaction with people they know to be homosexual, or conversely, those who have had more frequent social interactions with gay people may have become less prejudiced due to disconfirmation of negative stereotypes.

Those who reported knowing more gay people were less likely to hold Ego-Defensive attitudes toward homosexuality than those who reported knowing fewer gay people. People who hold Ego-Defensive attitudes are probably reluctant to interact with homosexuals because of feelings of discomfort or revulsion that are evoked. Heterosexual people who feel more secure regarding their own sexuality might be less inhibited about interacting with gays. Also, it is possible 
that knowing more gay people may decrease Ego-Defensive attitudes because one's self-identity may be clarified through a process of social comparison based on knowledge rather than on stereotypical beliefs.

Political behavior was found to vary as a function of level of Ego-Defensive attitude. Anti-gay rights activity was strongly predicted by Ego-Defensive attitudes. This supports the finding that those who hold defensive attitudes may engage in attacking the perceived source of threat, as well as using avoidance (Kirk \& Madsen, 1989), as a means of reducing feelings of threat.

The hypothesis that men are more likely to hold Ego-Defensive attitudes than are women was also supported, replicating Herek's (1986b) finding. In Herek's view this finding has its roots in the social construction of masculinity. Perhaps the negative consequences of deviance from socially mandated heterosexuality are perceived as being more immediate and/or more severe for men.

Those having more education were also somewhat more likely to agree with the statement supporting civil liberties for all, a finding that is consistent with other studies previously reviewed. Bobo and Licari (1989) attributed this effect to increased cognitive sophistication produced by more years of education. More education is likely to increase knowledge and improve critical thinking skills through practice. 
As predicted, those who agreed most strongly with the Value-Expressive statement "MY opinions regarding legal rights for homosexuals mainly are based on my moral beliefs about how things should be" were more likely to engage in anti-gay rights behavior. This prediction assumed that many respondents would interpret "moral beliefs" as pertaining to sanctioned sexual behavior, a notion popularized by religious teachings. It was thought that those who frame moral beliefs on this issue as meaning personal approval or disapproval of homosexuality would be likely to respond differently than those who view their moral beliefs on this issue as pertaining to equitable treatment of others.

The poor inter-item reliability of the two Value-Expressive items in the AFI and their failure to be confirmed by factor analysis requires explanation. The two items do intuitively relate to values. But their degree and direction of correlation is likely to vary depending upon an individual's construct of "moral behavior" and "moral beliefs", as mentioned above. For some people, "moral beliefs" narrowly refers to beliefs regarding certain socially or religiously specified sexual activities. Therefore those who adhere to such a definition and believe that homosexuality is immoral or sinful would probably be less likely to support legal rights for homosexuals. For others, the meaning of "moral beliefs" is a much broader construct, incorporating the requirement of moral agency in 
a decision-making process that may take both situational and outcome variables into account across a wide variety of situations. Thus "moral beliefs" may mean something very different to those who support civil rights protections for everyone. For these respondents "morality" may be more likely to mean something along the line of "acting in a responsible and equitable way toward others who may or may not be like me." Depending upon one's ethical philosophy, many constructs of morality may actually exist (see Keeney, 1984). While beliefs and values regarding civil liberties may actually be incorporated within the broader construct of "moral behavior" for many people, the popular use of the term "morality" to refer to sanctioned sexual behavior may mask the relationship between the Value-Expressive items regarding civil liberties and moral beliefs.

It should also be noted that the statement regarding civil liberties appeared to have a high degree of social desirability, with $82 \%$ of the respondents agreeing to some extent, while only $9 \%$ expressed any disagreement. Therefore, the ability of this item to differentiate between subjects is questionable. (Had the question been presented in an anonymous written questionnaire rather than via telephone, it is possible that responses may have varied more.)

For the reasons discussed above, should Herek's Value-Expressive subscale fail to replicate in future 
studies, when the attitude object is a social issue perhaps an attempt should be made to differentiate the Value-Expressive function on the basis of respondents' constructs regarding moral behavior rather than on the present items regarding civil liberties and moral beliefs. Perhaps an open-ended question, asking the respondent to define "moral behavior", might be used initially. Or, respondents could be asked whether they agree or disagree with statements containing different definitions of moral behavior.

The fact that the studies by Herek (1987) and Anderson and Kristiansen (1990) used only college students while this study used a more heterogenous sample might also account for differences in findings regarding the Value-Expressive items. Respondents of a similar cohort, class background and educational level might well be expected to show less variance in scores than a sample that differs across each of these variables. The impact of demographic variables on attitudes toward gay rights is well documented.

Potential limitations of the present study include the fact that the study was cross-sectional and therefore not reflective of changes over time, that the sample was drawn from one demographic location (limiting generalizability), that the sample size was not very large (increasing sampling error effects), that some segments of the local voter population may not have been included in the sample (since 
some may not have a telephone), that the interviewer was inexperienced and has a non-regional accent (which, for some, may have been difficult to understand), that the sex of those who refused to be interviewed was not recorded, that the AFI may be too cognitively difficult for some respondents (especially when it is presented by oral interview), and that responses on some of the questions may have been influenced by social desirability. The fact that in the above-mentioned studies the AFI was administered as a pen-and-pencil test with a 9-point Likert scale, while the present study used an orally administered AFI on a 7-point Likert scale, may have given rise to some differences in AFI scores. A 9-point scale provides the opportunity to achieve more response variability than does a 7-point scale. Some respondents in the present study seemed to have difficulty understanding and responding to the AFI statements. The telephone interview method was used because it was relatively inexpensive and was deemed likely to produce the desired response rate.

Since the response rate was over the projected $60 \%$ and the randomly selected sample appeared to be fairly well distributed, the findings of this study might reasonably be expected to have good generalizability to the Portland metropolitan voter population. Sampling error limits imposed by the relatively small sample size, however, should be taken into consideration. It should also be noted that 
respondents in this urban sample had relatively high levels of education and experience with gay people, both of which are likely to influence attitudes and political behavior toward the issue of gay civil rights. Therefore different results might be obtained in a demographically different sample. Conducting a similar study that compares a larger sample of voters from other locations should disclose differences where they exist.

A future study might ideally benefit from using a written response format in which respondents prioritize their AFI responses. Having each respondent prioritize the 10 attitude function items might provide greater insight into how they are actually used by individuals.

The method used for randomly selecting residential telephone numbers, suggested by Lake and Harper (1987), did not appear to provide the hoped-for advantage of reducing non-residential calls. Therefore, it is recommended that in the future a less time-consuming method of random number selection be used. It is also recommended that the sex of those who refuse to be interviewed should be recorded in order to ascertain potential differences in response rates between men and women.

The question of legal rights for homosexual (and bisexual) citizens remains a volatile political issue. While lesbians and gay men continue to work to obtain equal rights and protections under the law, members of the far 
right have attempted to garner political support by taking advantage of the negative emotions associated with homophobia, sexism and racism and that may be attached to issues such as gay rights, abortion and affirmative action. This tactic serves to drive a wedge between community groups that might otherwise be political allies.

Following the recent break-up of the USSR and the social and economic deterioration that has occurred in this country during the last decade, the far right has turned its focus of attention from a perceived communist threat to "cultural warfare". Many of their censorship efforts are currently focused on issues regarding human sexuality and gender roles, particularly on homosexuality, sex education and reproductive choice. Libraries and school textbooks, funding for the National Endowment for the Arts and National Public Radio, sexual behavior research, and womens' reproductive rights have been recent targets for attack, along with legal rights of homosexuals. Homosexuals are being portrayed as symbols of the "moral decay" that right-wing conservatives hold to be the cause of our societal ills.

It is hoped that by achieving an understanding of the underlying psychological functions of peoples' attitudes and their relationship to political behavior, that more effective ways may be found to thwart authoritarian and 
anti-democratic forces that foster fear, hatred and oppression.

For example, if Ego-Defensive attitudes are most predictive of anti-gay behavior, a concentrated effort might be made to reduce such attitudes by employing anti-bias curricula and sex education to eliminate the stigma associated with homosexual and bisexual orientations, while providing insight and bolstering self-esteem in the Ego-Defensive person. Additionally, teaching critical thinking skills might allow development of a broader and more humane construct of moral behavior. (Unfortunately, right-wing fundamentalists are actively opposed to any attempt to reduce the stigma attached to homosexuality. In oregon, these activist fundamentalists are currently attempting to incorporate language into the state constitution which would describe homosexuality as "abnormal, wrong, unnatural, and perverse" behavior that is to be "discouraged and avoided.")

Efforts to change attitudes are more likely to succeed when they coincide with the functions being served by those attitudes. Pryor, Reeder and McManus (1991) found that an AIDS education film, which addressed instrumental (Experiential-Schematic) concerns about working with someone who is infected, was only effective in improving attitudes of those who were not anti-gay. They concluded, "For those who hold negative attitudes toward homosexuality, AIDs may 
symbolize homosexual promiscuity and moral decadence" ( $p$. 134). Such symbolic attitude functions must also be addressed if persuasive efforts are to be successful. Herek (1986a) has suggested changing the consequences when an attitude is expressed, i.e. changing perceptions regarding social norms (Social-Expressive), evoking other held values (Value-Expressive), and stripping an attitude object of its symbolic link to an existing intrapsychic conflict through insight (Ego-Defensive). Citing DeBono's research, Tesser and Shaffer (1990) indicated that people:

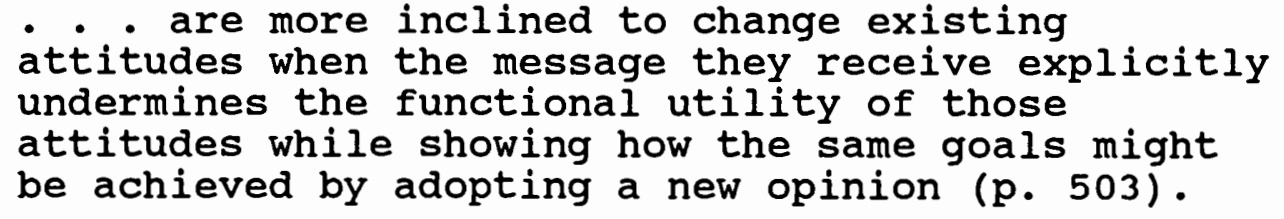

Further research is needed to ascertain effective ways of accomplishing this in order to alter the motivations that lead to the oppression of others. 
REFERENCES

Aguero, J. E., Bloch, L., \& Byrne, D. (1984). The relationships among sexual beliefs, attitudes, experience, and homophobia. Journal of Homosexuality, 10 , 95-107.

Ajzen, I. (1989). Attitude structure and behavior. In Pratkanis, A. R., Breckler, S. J., \& Greenwald, A. G. (Eds.), Attitude structure and function. Hillsdale, NJ: Lawrence Erlbaum Associates.

Ajzen, I., \& Fishbein, M. (1980). Understanding attitudes and predicting social behavior. Englewood-cliffs, NJ: Prentice-Hall.

Allport, G. W. (1954) . The nature of prejudice. Reading, MA: Addison-Wesley.

Anderson, D. S., \& Kristiansen, C. M. (1990). Measuring attitude functions. The Journal of Social Psychology, $130,419-421$.

Bobo, L. \& Licari, F. C. (1989). Education and political tolerance: Testing the effects of cognitive sophistication and target group affect. Public opinion Quarterly, 53, 285-308.

Cohn, S. (June 1992). LCP named in lawsuit. on Track, p. $1-2$.

Diamond, S. (1989) - Spiritual warfare: The politics of the christian right. Boston: South End Press.

Fiske, S. T., \& Taylor, S. E. (1991). Social cognition. McGraw-Hill.

Green, D. P, \& Waxman, L. M. (1987). Direct threat and political tolerance. Public opinion Quarterly, 51, 149-165.

Herek, G. M. (1984). Beyond "homophobia": A social psychological perspective on attitudes toward lesbians and gay men. Journal of Homosexuality, 10, 2-17.

Herek, G. M. (1986a). The instrumentality of attitudes: Toward a neofunctional theory. Journal of Social Issues, 42 , 99-114. 
Herek, G. M. (1986b). On heterosexual masculinity. American Behavioral Scientist, 29, 563-577.

Herek, G. M. (1987). Can functions be measured? A new perspective on the functional approach to attitudes. Social Psychology Quarterly, 50, 285-303.

Herek, G. M. (1989). Hate crimes against lesbians and gay men: Issues for research and policy. American Psychologist, 44, 948-955.

Hill, G. K. (1991, September 24). Hate crimes rise 46\%. The oregonian, pp. A1, A14.

Keeney, R. I. (1984). Ethics, decision analysis, and public risk. Risk Analysis, $4,117-129$.

Kite, M. E. (1984). Sex differences in attitudes toward homosexuals: A meta-analytic review. Journal of Homosexuality, 10, 69-81.

- Kirk, M., \& Madsen, H. (1989). After the ball: How america will conquer its fear and hatred of gays in the 90's. New York: Doubleday.

Lake, C. C, \& Harper, P. C. (1987) . Public opinion polling: A handbook for public interest and citizen advocacy groups. Washington, D. C.: Island Press.

Melton, G. B. (1989) . Public policy and private prejudice: Psychology and law on gay rights. American Psychologist, 44, 933-940.

Monje, K. (1992, May 21). Springfield vote win heartens OCA head. The Oregonian, p. G8.

ottati, V. C. (1990). Determinants of political judgments: The joint influence of normative and heuristic rules of inference. Political Behavior, 12, 159-179.

Potter, T. (1991, September 25). Testimony before Portland city council.

Pryor, J. B., Reeder, G. D., \& McManus, J. A. (1991) . Fear and loathing in the workplace: Reactions to AIDS-infected co-workers. Personality and Social Psychology Bulletin, 17, 133-39.

Rubenstein, S. (1992, January 16). Three Portland-area businesses try to block political petitioning. The oregonian, p. B5. 
Schneider, W. (1987). Homosexuals: Is AIDS changing attitudes? Public Opinion, July/Aug, pp. 6-7, 59.

Schneider, W., \& Lewis, I. A. (1984). The straight story on homosexuality and gay rights. Public opinion, Feb/Mar, pp. 16-20, 59-60.

Sears, D. O. (1988). Symbolic racism. In Katz, P. A. \& Taylor, D. A. (Eds.), Eliminating racism: Profiles in controversy. New York: Plenum.

Sears, D. O., Lau, R. R., Tyler, T. R., \& Allen, H. M., Jr. (1980). Self-interest or symbolic politics in policy attitudes and presidential voting. American Political Science Review, 74, 670-684.

Sorensen, I. (1991, July). Bias/hate crimes unit. Just out, p. 12 .

Stoddard, T. B., Boggan, E. C., Haft, M. G., Lister, C., \& Rupp, J. P. (1983). The rights of gay people. New York: Bantam.

Sullivan, J. L., \& Marcus, G. E. (1988). A note on "trends in political tolerance". Public opinion Quarterly, 52, 26-32.

Tesser, A., \& Shaffer, D. R. (1990). Attitudes and attitude change. Annual Review of Psychology, 41, 479-523.

The homosexuals' agenda: Will it destroy America? (1991, April/May). The Oregon Alliance, pp. 1, 4 .

- Whitley, B. E., Jr. (1990). The relationship of heterosexuals' attributions for the causes of homosexuality to attitudes toward lesbians and gay men. Personality and Social Psychology Bulletin, 16, 369-377. 
APPENDIX A

HEREK'S (1987) ATTITUDE FUNCTIONS INVENTORY 


\section{Attitude Functions Inventory (AFI)}

(The order in which these were asked was randomly changed in 4 versions of the questionnaire.)

\section{Experiential-schematic}

1. My opinions about gay rights (legal rights for gay people/homosexuals) mainly are based on whether or not someone I care about is gay.

2. My opinions about gay rights mainly are based on my personal experiences with specific gay persons.

3. My opinions about gay rights mainly are based on my judgment of how likely it is that I will interact with gay people in any significant way.

4. My opinions about gay rights mainly are based on my personal experiences with people whose family members or friends are gay.

\section{Social-Expressive}

5. My opinions about gay rights mainly are based on my perceptions of how the people I care about have responded to gay people.

6. My opinions about gay rights are based on learning how this issue is viewed by the people whose opinions I most respect.

\section{Defensive}

7. My opinions about gay rights mainly are based on the fact that I would rather not think about homosexuality or gay people.

8. My opinions about gay rights mainly are based on my personal feelings of discomfort or revulsion at homosexuality.

\section{Value-Expressive}

9. My opinions about gay rights mainly are based on my concern that we safeguard the civil liberties of all people in our society.

10. My opinions about gay rights mainly are based on my moral beliefs about how things should be. 


\section{APPENDIX B}

QUESTIONNAIRE:

ATTITUDE FUNCTIONS AND POLITICAL BEHAVIOR:

THE ISSUE OF GAY CIVIL RIGHTS 


$\begin{array}{ccccccc}\text { QUESTIONNAIRE } & \text { VERSION (circle) } & 1 & 2 & 3 & 4 \\ \text { DATE } & \text { INTERVIEW NO. } & & & & \end{array}$

Good evening, my name is Josephine Young. I'm a graduate student at Portland state University and I'm conducting a study of voters' attitudes for my master's thesis. Your phone number was randomly selected to participate in this survey. Are there any members of your household who are registered to vote in Oregon?

(IF NO, TERMINATE WITH:) This study requires registered Oregon voters. Thanks for your time.

(IF YES, CONTINUE WITH:) of those registered voters, may I speak with the one who has most recently had a birthday? FQ YES)

(IF ELIGIBLE RESPONDENT HAS ANSWERED THE PHONE, GO TO

(IF ELIGIBLE RESPONDENT IS NOT AVAILABLE, ASK:) When is a good time for me to call back to speak with him or her?

(IF RESPONDENT IS OTHER THAN THE PERSON WHO ANSWERS THE PHONE, REPEAT:)

Good evening, my name is Josephine Young. I'm a graduate student at Portland state University and I'm conducting a study of voters' attitudes for my master's thesis. Your phone number was randomly selected to participate in this survey. (THEN GO TO FQ)

(IF RESPONDENT ASKS HOW THEY WERE SELECTED:) "A PROCEDURE WAS USED IN WHICH A DIGIT WAS ADDED TO RANDOMLY SELECTED TELEPHONE NUMBERS SO THAT THE SURVEY MAY INCLUDE SOME UNLISTED NUMBERS. I DON'T KNOW WHO LIVES AT ANY OF THE HOUSEHOLDS THAT I AM CALLING. YOUR TELEPHONE NUMBER WILL NOT BE RECORDED ON THE QUESTIONNAIRE, SO NO ONE, INCLUDING MYSELF, WILL KNOW WHO YOU ARE."

(IF RESPONDENT ASKS WHAT I PLAN TO DO WITH THIS INFORMATION:) "THIS IS A STUDY OF VOTER'S ATTITUDES AND POLITICAL BEHAVIOR THAT I'M DOING FOR MY MASTER'S THESIS AT PORTLAND STATE UNIVERSITY.")

(IF RESPONDENT ASKS WHY I'M ASKING ABOUT GAY RIGHTS:) "THIS ISSUE HAS BEEN GETTING A LOT OF MEDIA COVERAGE LATELY. IT'S AN ISSUE THAT MANY PEOPLE HAVE STRONG FEELINGS ABOUT AND ONE THAT VOTERS MAY SOON BE ASKED TO VOTE ON."

FQ. Are you registered to vote in oregon?

YES : This survey will take about 15 minutes. All of your answers will remain anonymous. You can refuse to answer any question if you wish, and you may stop at any time. When we're done I'll tell you how you may obtain the results of the study if you'd like. (CONTINUE TO Q1.) 
NO : TERMINATE WITH: This study requires people who are registered to vote in oregon. Thanks for your time.

REFUSAL : IF PERSON DECLINES TO PARTICIPATE, STOP WITH: Thank you. Is there anything you'd like to say before we hang up? TALK, ASK:

IF RESPONDENT INDICATES IT IS NOT A CONVENIENT TIME TO back?

Is there a convenient time that I may call

Q1. During the past few months, have you heard or read anything about the issue referred to in the media as gay rights, that is, legal rights for people who are identified as homosexual, gay or lesbian?
1.1 NO
1.2 YES
1.3 DON'T KNOW

Q2. Would you say that this issue is of great concern, moderate concern, slight concern, or no concern at all to you?

$$
\begin{array}{ll}
2.1 & \text { GREAT CONCERN } \\
2.2 & \text { MODERATE CONCERN } \\
2.3 & \text { SLIGHT CONCERN } \\
2.4 & \text { NO CONCERN AT ALL } \\
2.5 & \text { DON'T KNOW }
\end{array}
$$

Q3. In general, do you consider yourself to be in favor of or opposed to gay rights? THEN ASK: Would you say that you are slightly, moderately, or strongly in favor of (or opposed to) gay rights?
FAVOR
3.1
STRONGLY 3.2 MODERATELY
3.3 SLIGHTLY
3.4 DON'T KNOW
OPPOSE
3.5 STRONGLY 3.6 MODERATELY
3.7 SLIGHTLY

Attitude Functions Inventory ( $Q 4$ THRU Q13.) (THE ORDER IN WHICH THESE WERE ASKED WAS RANDOMLY CHANGED IN FOUR VERSIONS OF THE SURVEY.)

Now I'd like for you to listen very carefully while I read 10 statements. Each statement contains a different reason that a person might use as a basis for their opinions regarding the issue of legal rights for homosexual men and women. Thinking about your own opinions about this issue, after each statement I'd like for you to indicate whether you slightiy, moderately, or strongly agree or disagree with that statement. These statements are sort of difficult, so let me know if I go too fast or if you'd like for me to repeat any of them. 
QA. Just for the sake of these questions, would you

rather I use the phrase "gay people" or "homosexuals", or do you care?

QA. 1 GAY PEOPLE

QA. 2 HOMOSEXUALS

QA. 3 DON'T CARE

Experiential-Schematic (Q4. THRU Q7.)

Q4. My opinions about legal rights for (gay people)

(homosexuals) mainly are based on whether or not someone I care about is (gay) (homosexual).

Would you say that you agree or disagree with that statement?

strongly, moderately, or slightly?

AGREE 4.1 STRONGLY 4.2 MODERATELY 4.3 SLIGHTLY

$\begin{array}{llll}4.4 \text { DON'T KNOW } & \text { KISAGREE } 4.7 \text { STRONGLY } & 4.6 \text { MODERATELY } & 4.5 \text { SLIGHTLY }\end{array}$

Q5. My opinions about legal rights for (gay people)

(homosexuals) mainly are based on my personal experiences with specific (gay persons) (people who are homosexual).

AGREE 5.1 STRONGLY 5.2 MODERATELY 5.3 SLIGHTLY

$\begin{array}{llll}5.4 & \text { DON'T KNOW } & \text { KISAGREE } & 5.7 \\ \text { STRONGLY } & 5.6 \text { MODERATELY } 5.5 \text { SLIGHTLY }\end{array}$

Q6. My opinions about legal rights for (gay people)

(homosexuals) mainly are based on my judgment of how likely

it is that I will interact with (gay people) (homosexuals)

in any significant way.

AGREE 6.1 STRONGLY 6.2 MODERATELY 6.3 SLIGHTLY

$\begin{array}{llll}6.4 \text { DON'T KNOW } & \text { DISAGREE } 6.7 \text { STRONGLY } 6.6 \text { MODERATELY } & 6.5 \text { SLIGHTLY }\end{array}$

Q7. My opinions about legal rights for (gay people)

(homosexuals) mainly are based on my personal experiences

with people whose family members or friends are (gay)

(homosexual).

AGREE $\quad 7.1$ STRONGLY 7.2 MODERATELY 7.3 SLIGHTLY

$\begin{array}{llll} & 7.4 \text { DON'T KNOW } & \\ \text { DISAGREE } & 7.7 \text { STRONGLY } & 7.6 \text { MODERATELY } 7.5 \text { SLIGHTLY }\end{array}$

Social-Expressive (Q8. \& Q9.)

Q8. My opinions about legal rights for (gay people)

(homosexuals) mainly are based on my perceptions of how the people I care about have responded to (gay people)

(homosexuals).

AGREE 8.1 STRONGLY 8.2 MODERATELY 8.3 SLIGHTLY

8.4 DON'T KNOW

DISAGREE 8.7 STRONGLY 8.6 MODERATELY 8.5 SLIGHTLY 
Q9. My opinions about legal rights for (gay people) (homosexuals) are based on learning how this issue is viewed by the people whose opinions I most respect.

AGREE 9.1 STRONGLY 9.2 MODERATELY 9.3 SLIGHTLY 9.4 DON'T KNOW

DISAGREE 9.7 STRONGLY 9.6 MODERATELY 9.5 SLIGHTLY

Defensive (Q10.\& Q11.)

Q10. My opinions about legal rights for (gay people)

(homosexuals) mainly are based on the fact that I would

rather not think about homosexuality or gay people.

AGREE 10.1 STRONGLY 10.2 MODERATELY 10.3 SLIGHTLY 10.4 DON'T KNOW

DISAGREE 10.7 STRONGLY 10.6 MODERATELY 10.5 SLIGHTLY

Q11. My opinions about legal rights for (gay people)

(homosexuals) mainly are based on my personal feelings of discomfort or revulsion at homosexuality.

AGREE 11.1 STRONGLY 11.2 MODERATELY 11.3 SLIGHTLY

DISAGREE 11.7 STRONGLY 11.6 MODERATELY 11.5 SLIGHTLY

Value-Expressive (Q12.\& Q13.)

Q12. My opinions about legal rights for (gay people)

(homosexuals) mainly are based on my concern that we

safeguard the civil liberties of all people in our society.

AGREE 12.1 STRONGLY 12.2 MODERATELY 12.3 SLIGHTLY

12.4 DON'T KNOW

DISAGREE 12.7 STRONGLY 12.6 MODERATELY 12.5 SLIGHTLY

Q13. My opinions about legal rights for (gay people)

(homosexuals) mainly are based on my moral beliefs about how things should be.

AGREE 13.1 STRONGLY 13.2 MODERATELY 13.3 SLIGHTLY 13.4 DON'T KNOW

DISAGREE 13.7 STRONGLY 13.6 MODERATELY 13.5 SLIGHTLY

Q14. Political Behavior Index

Thanks. Now I'm going to read a list of activities regarding the issue of legal rights for (gay people) (homosexuals), or gay rights, and I'd like for you to indicate which of these, if any, you have participated in during the past four years. (ASK WHETHER FOR Or AGAINST WHERE NECESSARY. SCORE AS +1 FOR EACH OCCURRENCE OF PRO-GAY RIGHTS ACTIVITY AND - 1 FOR EACH OCCURRENCE OF ANTI-GAY RIGHTS ACTIVITY.)

During the past four years, have you:

14.1 WRITTEN A LETTER TO THE NEWSPAPER SUPPORTING OR OPPO SING GAY RIGHTS

14.2 ATTENDED A PUBLIC HEARING ON THIS ISSUE? 
14.3 WRITTEN OR TALKED TO YOUR LEGISLATOR OR OTHER PUBL IC OFFICIAL ABOUT THIS ISSUE? 14.4 GATHERED SIGNATURES FOR AN INITIATIVE REGARDING THE ISSUE OF GAY RIGHTS OR SEXUAL ORIENTATION? 14.5 SIGNED AN INITIATIVE OR PETITION REGARDING LEGAL RIGHTS OF (HOMOSEXUALS) (GAY PEOPLE)? 14.6 DONATED MONEY TO AN ORGANIZATION THAT IS ACTIVELY INVOLVED IN THIS ISSUE?

14.7 PARTICIPATED IN MARCHES, RALLIES OR PUBLIC DEMONSTRATIONS OR PUBLIC ACTIONS RELATED TO THE ISSUE OF GAY RIGHTS?

14.8 SPOKEN PUBLICLY (TO A GROUP) ABOUT THIS ISSUE?

14.9 SOLICITED THE INVOLVEMENT OF OTHERS REGARDING THIS ISSUE? 14.10 TAKEN A POSITION FOR OR AGAINST GAY RIGHTS IN CONVERSATIONS OR DISCUSSIONS?

14.11 DISPLAYED BUMPER STICKERS, BUTTONS, OR YARD SIGNS REGARDING THIS ISSUE?

14.12 SUPPORTED OR OPPOSED A POLITICAL CANDIDATE BECAUSE OF HIS OR HER STANCE ON THIS ISSUE?

14.13A_HAVE YOU EITHER BOYCOTTED OR SUPPORTED ANY

BUSINESSES BECAUSE OF THIS ISSUE?

14.13B CAN YOU THINK OR ANY OTHER ACTIVITIES THAT YOU'VE BEEN INVOLVED WITH REGARDING THIS ISSUE? (LIST)

14.14_An initiative has been proposed that would keep the state legislature from passing laws to prevent discrimination on the basis on sexual orientation. Additionally, this proposed initiative would require public schools to set a standard that presents homosexuality as being "abnormal, wrong, unnatural and perverse." If this initiative gets on the ballot this year, do you plan to vote for or against it?

$\begin{array}{ll}\text { FOR } & (-1) \\ \text { AGAINST } & (+1) \\ \text { DON'T KNOW } & (0)\end{array}$

14.15 The Portland city council recently passed an ordinance that makes it illegal to discriminate against people in employment, housing, and public accommodations because of their sexual orientation. ("SEXUAL ORIENTATION" IS CURRENTLY DEFINED AS HETEROSEXUALITY, HOMOSEXUALITY OR BISEXUALITY.) If you had a chance to vote either to overturn or to keep this ordinance in place, how do you think you would vote?

$\begin{array}{ll}\text { OVERTURN ORDINANCE } & (-1) \\ \text { KEEP ORDINANCE } & (+1) \\ \text { DON'T KNOW } & (0)\end{array}$


14.16FQ Were you a registered oregon voter in 1988? Q17.)

(IF YES OR DON'T REMEMBER, CONTINUE. IF NO, SKIP TO

14.16 In November 1988 Oregon voters passed a ballot measure known as Ballot Measure 8. It overturned an order by Governor Goldschmidt that had made it illegal to discriminate against anyone within the executive branch of state government because of their sexual orientation. Did you vote YES in 1988 to overturn the governor's order prohibiting discrimination, or did you vote no against that ballot measure?

$$
\begin{array}{ll}
\text { VOTED YES } & (-1) \\
\text { VOTED NO } & (+1)
\end{array}
$$

DIDN'T VOTE Or DOESN'T REMEMBER (0)

Q15. If the vote were being held today, do you think that you would vote the same way as you did back in 1988, or would you vote differently now?

15.1 SAME

15.2 CHANGE

15.3 DON'T KNOW

(IF CHANGE)

Q16. Could you tell me a little about why you would change your vote? (open)

TOTAL UNITARY SCORE (i.e. PER ACTIVITY) FOR POLITICAL BEHAVIOR INDEX

Q17. Do you think the law should allow an employer to fire an employee for being homosexual, or should the law keep an employer from firing someone because he or she is gay?

17.1 ALLOW FIRING

17.2 PREVENT FIRING

17.3 DON'T KNOW

Q18. In your opinion, do laws that prohibit discrimination on the basis of sexual orientation give special rights to people who are homosexual?
18.1 YES
18.2 NO
18.3 DON'T KNOW

Q19. Would you like to explain your answer a little? (open) 
Q20. In your opinion, should gay couples receive the same spousal benefits (such as health insurance, social security, etc.) as heterosexual couples?

21.1 YES

21.2 NO

21.3 DON'T KNOW

Q21. Do you think that two people of the same sex should be allowed to marry?

20.1 YES

20.2 NO

20.3 DON'T KNOW

Q22. Do you think that hate crimes directed against homosexuals are highly related, somewhat related, or unrelated to the legal status of gay people? ("HATE CRIMES" ARE CRIMES, SUCH AS ASSAULT, THAT ARE MOTIVATED BY

PREJUDICE.)

22.1 HIGHLY RELATED

22.2 SOMEWHAT RELATED

22.3 UNRELATED

22.4 DON'T KNOW

Q23. About how many lesbians and gay men would you say that have you ever personally known:

none, one, 2 to 5 , more than 5?

23.1 NONE

23.2 ONE

23.32 TO 5

23.4 MORE THAN 5

23.5 DON'T KNOW

Q24. Of those (gay people) (homosexuals) you have known, which of the following categories did they fall into:

24.1

24.2 RELATIVES?

24.3 FRIENDS?

24.4 CO-WORKERS?

24.5 CLASSMATES?

24.6 NEIGHBORS?

ACOUAINTANCES?

24.7_ ARE THERE ANY OTHERS?

Q25. During the past year, would you say that you socially interacted with (gay people) (homosexuals) frequently, occasionally, rarely, or not at all?

25.1 FREQUENTLY

25.2 OCCASIONALLY

25.3 RARELY

25.4 NOT AT ALL

25.5 DON'T KNOW 
Q26. Would you say that your interactions with (gay people) (homosexuals) have been mostly pleasant or mostly unpleasant?

26.1 MOSTLY PLEASANT

26.2 MOSTLY UNPLEASANT

26.3 EQUALLY PLEASANT AND UNPLEASANT

26.4 DON'T KNOW

Q27. Thinking of the people who you are closest to, would you say that most of them are for or against gay rights?

27.1 MORE ARE FOR

27.2 MORE ARE AGAINST

27.3 ABOUT EQUALLY DIVIDED FOR AND AGAINST

27.4 DON'T KNOW

DEMOGRAPHICS

We're just about finished now, but I'd like to ask you a few last questions about yourself:

Q28. Are you:

28.1 under the age of 30 ?

28.2 between 30 and 39 ?

28.3 between 40 and 49 ?

28.4 between 50 and 59 ?

28.5 age 60 or over?

Q29. Regarding marital status, are you:

29.1 EITHER MARRIED OR ENGAGED?

29.2 WIDOWED, SEPARATED OR DIVORCED?

29.3 UNMARRIED BUT IN A COMMITTED RELATIONSHIP?

29.4 SINGLE, HAVING NEVER BEEN MARRIED?

29.5 OTHER

Q30. Do you consider yourself close to any political party? 30.1 NO

30.2 YES

30.3 DON'T KNOW

Q31. (IF YES TO Q30:) Which one?

31.1 NONE

31.2 DEMOCRAT

31.3 REPUBLICAN

31.4 INDEPENDENT

31.5 OTHER

31.6 DON'T KNOW

Q32. Do you consider yourself to be CONSERVATIVE, MODERATE, Or LIBERAL?

32.1 CONSERVATIVE

32.2 MODERATE

32.3 LIBERAL 
32.4 OTHER

34.5 DON'T KNOW

Q33. What was the last grade of school that you completed?

33.1 ELEMENTARY

33.2 JUNIOR HIGH

33.3 HIGH SCHOOL

33.4 SOME COLLEGE

33.5 COLLEGE

33.6 GRADUATE SCHOOL

Q34. What, if any, is your religious affiliation at present?

$34 . \overline{1}$ NONE

34.2 PROTESTANT (DENOMINATION?

34.3 CATHOLIC

34.4 JEWISH

34.5 OTHER (DENOMINATION?

Q35. During the past year, about how many times would you say that you attended religious services:

none, 1 to 3 times, 4 to 12 times, more than 12 times. 35.1 NEVER

35.2 SELDOM ( 1 TO 3 TIMES PER YEAR)

35.3 OCCASIONALLY (4 TO 12 TIMES PER YEAR)

35.4 OFTEN (MORE THAN 12 TIMES PER YEAR)

35.5 DON'T KNOW

QG. (RESPONDENT GENDER:)

QG. 1 MALE

QG. 2 FEMALE

That's the end of the survey! Thank you very much for your help!

Would you like to know how you can find out the results of this study?

(IF YES:) Send a stamped, self-addressed envelope to me, Josephine Young, in care of the Psychology Dept., P. 0 . Box 751, Portland State University, Portland, OR 97207. Be sure to send your request before June 1, 1992 .

Before we hang up, is there anything else you'd like to say about the gay rights issue or about this survey?

Thanks again for your help! Goodbye. 